NAA-SR-6109

METALS, CERAMICS, AND

MATERIALS

58 PAGES

\title{
PERMEABILJTY OF METALS
}

AND ENAMELED METALS TO HYDROGEN

By

DAVID W. RUDD*

J. B. VETRANO

* Metal Hydrides, Inc.

\section{ATOMICS INTERNATIONAL}

A DIVISION OF NORTH AMERICAN AVIATION, INC. P.O. BOX 309 CANOGA PARK, CALIFORNIA

CONTRACT: AT(11-1)-GEN-8

ISSUED:

DCT 301969 


\section{DISCLAIMER}

This report was prepared as an account of work sponsored by an agency of the United States Government. Neither the United States Government nor any agency Thereof, nor any of their employees, makes any warranty, express or implied, or assumes any legal liability or responsibility for the accuracy, completeness, or usefulness of any information, apparatus, product, or process disclosed, or represents that its use would not infringe privately owned rights. Reference herein to any specific commercial product, process, or service by trade name, trademark, manufacturer, or otherwise does not necessarily constitute or imply its endorsement, recommendation, or favoring by the United States Government or any agency thereof. The views and opinions of authors expressed herein do not necessarily state or reflect those of the United States Government or any agency thereof. 


\section{DISCLAIMER}

Portions of this document may be illegible in electronic image products. Images are produced from the best available original document. 


\section{DISTRIBUTION}

This report has been distributed according to the category Metals, Ceramics, and Materials" as given in "Standard Distribution Lists for Unclassified Scientific and Technical Reports" TID-4500 (16th Ed.), December 15, 1960. A total of 620 pages was printed.

\section{ACKNOWLEDGMENT}

The assistance of Professors Dwight G. Bennett and Julian $\dot{H}$. Lauchner of the Ceramic Engineering Department, University of Illinois, is gratefully acknowledged. Dr. Lauchner prepared all the glass coatings studied in this report and instructed us in the method of application and firing. The advice, assistance, and encouragement of Dr. Sidney Johnson, Assistant Director of Research, Metal Hydrides, Inc., is sincerely appreciated. 


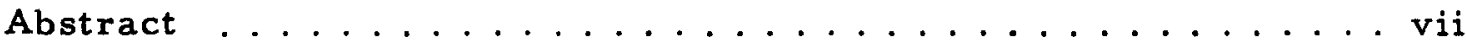

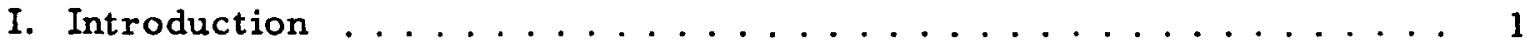

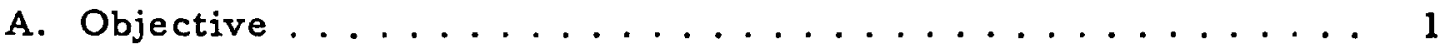

B. General Theory of Permeation................ 1

C. Permeability Equations. . . . . . . . . . . . . . . 2

D. Chief Factors Affecting Permeation ............. 3

E. Miscellaneous Factors Affecting Permeation . . . . . . . . 4

II. Experimental Procedure .................... 5

A. Apparatus Used in Previous Investigations . . . . . . . . . 5

B. Apparatus Used in These Investigations . . . . . . . . . . 7

III. Permeability of AISI-Type 430 Stainless Steel to Hydrogen . . . . 13

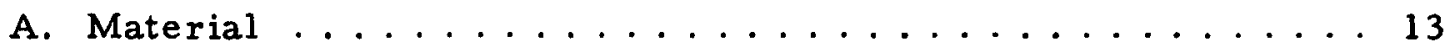

B. Accuracy of Measurements ................ 13

C. Data ............................... 14

IV. Permeability of AISI-Type 321 Stainless Steel to Hydrogen $\ldots \ldots 18$

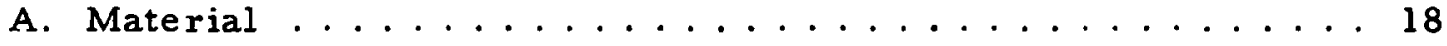

B. Accuracy of Measurements ................. 18

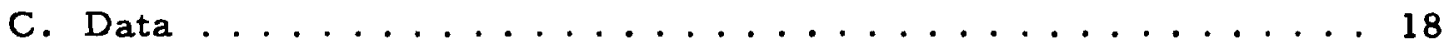

V. Permeability of Calorized AISI-Type 430 Stainless Steel

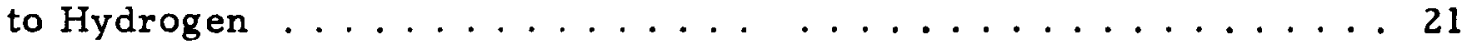

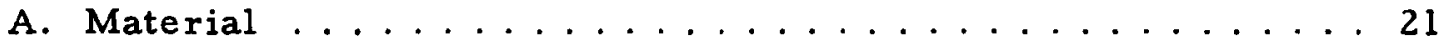

B. Accuracy of Measurements ............... 21

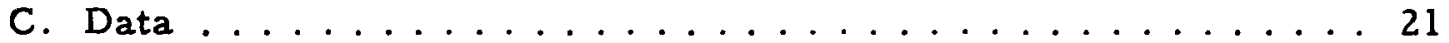

VI. Rate of Hydrogen Permeation Through Solar-Coated Hastelloy B . . 29

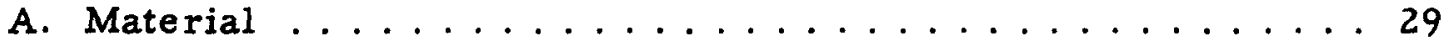

B. Accuracy of Measurements . . . . . . . . . . . . 29

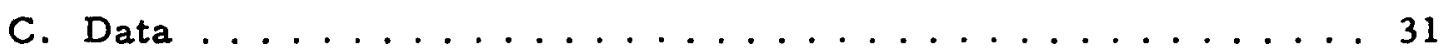

VII. Rate of Hydrogen Permeation Through J-2 and J-8 Glasses. . . . . 39

A. Material ........................... 39

B. Accuracy of Measurements . . . . . . . . . . . . . 40

C. Data .............................. 40

NAA-SR-6109 


\section{CONTENTS}

VIIl. Rate of Hydrogen Permeation Through J-5 Glass . . . . . . . . 45

A. Material ........................... 45

B. Accuracy of Measurements .................47

C. Data ............................. 47

IX. Summary and Conclusions ..................... 49

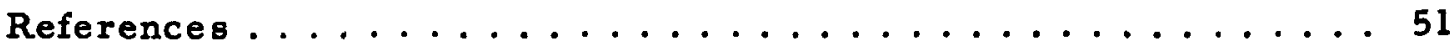

\section{TABLES}

I. Rate of Hydrogen Permeation Through AISI-Type 430

Stainle ss Steel Membrane No. $1 \ldots \ldots \ldots$

II. Rate of Hydrogen Permeation Through AISI-Type 430

Stainle Bs Steel Membrane No. 2 ............... 16

III. Rate of Hydrogen Permeation Through AISI-Type 430

Stainless Steel Membrane No. $3 \ldots \ldots \ldots 17$

IV. Rate of Hydrogen Permeation Through AISI-Type 321

Stainless Steel. . . . . . . . . . . . . . . . . . 19

V. Permeability of AISI-Type 321 Stainless Steel to Hydrogen at One Atmosphere .................. 20

VI. Rate of Hydrogen Permeation Through Calorized AISI-Type 430 Stainle s8 Steel Membrane No. $1 \ldots \ldots . . \ldots . . . \ldots 22$

VII. Summary of Data for Rate of Hydrogen Permeation Through Calorized AISI-Type 430 Stainless Steel Membrane No. 1 . . . . 23

VIII. Rate of Hydrogen Permeation Through Calorized AISI-Type 430 Stainless Steel Membrane No. 2 . . . . . . . . . . . . . . 24

IX. Summary of Data for Rate of Hydrogen Permeation Through Calorized AISI-Type 430 Stainle ss Steel Membrane No. 2 . . . . 25

X. Rate of Hydrogen Permeation Through Calorized AISI-Type 430 Stainles s Steel Membrane No. $3 \ldots \ldots$............... 26

XI. Summary of Data for Rate of Hydrogen Permeation Through Calorized AISI-Type 430 Stainle ss Steel Membrane No. 3 . . . . . 27

XII. Rate of Hydrogen Permeation Through Hastelloy B + Solar Coated Membrane No. $1 \ldots \ldots$................. 30

XIII. Summary of Data for Rate of Hydrogen Permeation Through Hastelloy B + Solar Coated Membrane No. 1............ 


\section{TABLES}

Page

XIV. Rate of Hydrogen Permeation Through Hastelloy B + Ceramic Coating Membrane No. 1, Inverted ............. 33

XV. Summary of Data for Rate of Hydrogen Permeation Through Hastelloy B + Ceramic Coating Membrane No. 1, Inverted . . . . 34

XVI. Rate of Hydrogen Permeation Through Solar-Coated Hastelloy B Membrane No. 2 ................. 35

XVII. Summary of Data for Rate of Hydrogen Permeation Through Solar-Coated Hastelloy B Membrane No. 2 . . . . . . . . . 36

XVIII. Rate of Hydrogen Permeation Through Solar-Coated Hastelloy B Membrane No. $\ldots \ldots \ldots$. . . . . . . . . 37

XIX. Summary of Data for Rate of Hydrogen Permeation Through Solar-Coated Hastelloy B Membrane No. $3 \ldots \ldots . \ldots . \ldots$

XX. Calculated Permeation Rate of Solar Coating $\left(R_{C}\right) \ldots \ldots$

XXI. Rate of Hydrogen Permeation Through Sample J-2-1 . . . . . . 43

XXII. Rate of Hydrogen Permeation Through Sample J-2-2 . . . . . . 44

XXIII. Summary of Data for Samples J-2-1 and J-2-2 . . . . . . . . . . 45

XXIV. Rate of Hydrogen Permeation Through Sample J-8 . . . . . . . . 46

XXV. Rate of Hydrogen Permeation Through Sample J-5 . . . . . . . . 48

\section{FIGURES}

1. Diffusion Apparatus of Other Investigators . . . . . . . . . 6

2. Detail of the Membrane .................... 7

3. Cross Section of Furnace Assembly ................ 8

4. Assembled Diffusion Membrane ................. 8

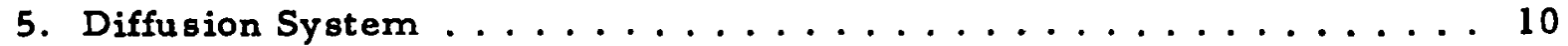

6. Membrane Furnace and Downstream Collection Line . . . . . . . . 11

7. Ordinary Manometer Collection and Measuring Volume. . . . . . . . 12

8. Calorized Mild Steel Specimen . . . . . . . . . . . . . . . 25

9. Membrane No. 1 after Permeation Testing . . . . . . . . . . . 27

10. Membrane No. 2 after Permeation Testing . . . . . . . . . . . 28

11. Surface of $\mathrm{J}-2-1$ Coating . . . . . . . . . . . . . . . . . . 40

12. Cross Section of J-2-2 Membrane at Corner Area . . . . . . . . . 41 


\section{FIGURES}

Page

13. Cross Section of J-8 Coating in the As-Fired Condition . . . . . . 41

14. Cross Section of J-8 Coating after Permeation Testing . . . . . . . 42

15. Cross Section of Corner of J-5-Coated Membrane after

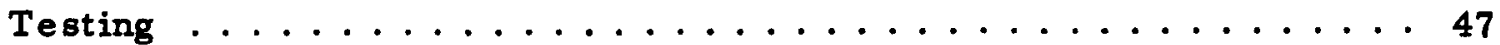

16. Comparison of Permeabilities of Several Materials at 1.1 Atmosphere of Hydrogen Pressure Differential . . . . . . . . 50 


\section{ABSTRACT}

The results of tests on permeability of various selected materials to hydrogen are reported. The investigation includes findings on metal, oxide-coated metal, and glass-coated metal systems. Where possible, the results are fitted to the known relationships of diffusion theory.

The report can be divided roughly into two parts, one dealing with the permeability of certain alloys to hydrogen, and the other with the permeability characteristics of various coated-metal membranes. The alloys include AISI Types-321 and 430 stainless steels and Hastelloy B. The coated metals include calorized AISIType 430 stainless steel, four glass-coated AISI-Type 304 stainless steels, and three systems of Hastelloy B coated with a proprietary material furnished by Solar Aircraft Co.

Measurements were made using a one-piece diffuser in which the membrane is a flat disc. The range of temperatures investigated was from 550 to $820^{\circ} \mathrm{C}$; and the pressures employed, 1.1 , 1.5 , and $2.0 \mathrm{~atm}$.

The metal alloys investigated had permeabilities uniformly much greater than surface-treated metals. As small an amount as 3 to 7 mils of a suitable, high-temperature glass enamel or $10 \mathrm{mils}$ of surface calorizing is still 10 to 100 times more effective as a hydrogen barrier than 60 to 120 mils of untreated steel. 


\section{INTRODUCTION}

\section{A. OBJECTIVE}

The object of this investigation was to gather information on the permeability to hydrogen of materials which could be utilized in the construction of hydridemoderated nuclear reactors.

\section{B. GENERAL THEORY OF PERMEATION}

The permeability of a solid to hydrogen or certain gases in general is thought to be a composite rate process involving processes of adsorption, solution, diffusion and desorption. ${ }^{1}$ Published literature on the permeability of solids to gases is quite voluminous. From these efforts, several facts are observed. First, the permeability of metals to diatomic gases involves the passage through the metal of the individual atoms of the permeating gas. This is evidenced by the fact that the permeation is dependent upon the square root of the pressure. Second, the gas permeates the lattice of the metal and not along grain boundaries or small fissures. It was shown by Smithells and Ransley ${ }^{2}$ that rate of permeation through single-crystal iron remained the same after the iron had been recrystallized into several smaller crystals. Third, the permeation of gases to metals is sperific in that only those gases which are dissolved by a metal can permeate it. Since, for instance, rare gases are not dissolved by metals, attempts to measure permeabilities of these gases have proved unsuccessful. Ryder ${ }^{3}$ found negative results on the permeability of iron to argon. Baukloh and Kayser ${ }^{4}$ found nickel impervious to helium, neon, argon, or krypton. Nitrogen is adsorbed by iron and molybdenum, but not by copper; and will permeate the former but not the latter. Fourth, it has been observed, at least for most common metals, that the rate of permeation is inversely proportional to the thickness of the solid membrane. Johnson and Larose ${ }^{5}$ determined the rate of permeation of oxygen through silver to be linearly dependent on the reciprocal thickness of various silver foils. Similar results were noted by Lombard $^{6}$ for the system hydrogen-nickel, and by Lewkonia and Baukloh ${ }^{7}$ for hydrogen-iron. This would tend to show that although adsorption is very im-

: portant, at least in determining whether permeation will ensue, it is not the rate-determining process. The opposite effect has been noticed in the case of hydrogen-Inconel, ${ }^{8}$ where due to a film forming on the surface, the resulting reaction of hydrogen with this film is rate-determining. 
The permeability studies of glasses and particularly complex glass-coated metals is considerably more difficult to interpret. If attention is limited to glasses themselves, the most general features are: first, Fick's diffusion law is followed; ${ }^{9}$ second, the steady state is established in a period of minutes, depending on the temperature; ${ }^{10}$ third, permeation rates are usually proportional to the pressure, and inversely proportional to the thickness of the membrane; fourth, the velocity of diffusion is only slightly altered by roughening the outgoing surface. 11

When the glass is applied to the metal, several things are noticed. First, the rate of permeation is reduced relative to the uncoated metal. Second, the temperature-dependence does not always exhibit the same behavior as in the case of metals. A plot of $\log$ rate $\mathrm{vs} 1 / \mathrm{T}$ is linear in the case of metals. In the case of a metal coated with glass, linearity is sometimes but not always observed. Third, rather long times are required for the attainment of a stationary flow rate. Fourth, reproducibility of results is not as good as in the case of metals. Fifth, the pressure dependence is either erratic or of the form

$$
\text { rate }=k p^{n}
$$

where

$$
\begin{aligned}
& \mathbf{p}=\text { hydrogen pressure (atm) and } \\
& \mathbf{n}=\text { a number determined by experiment. }
\end{aligned}
$$

Sixth, the temperature, pressure and rate factors are different if the sample is inverted so that the hydrogen permeates the metal first.

\section{PERMEABILITY EQUATIONS}

The equation which is used to evaluate the quantity of gas permeating a metal barrier is usually written in the form

$$
a=\frac{k D A}{x} t\left[p_{1}^{1 / 2}-p_{2}^{1 / 2}\right] e^{-E_{p} / R T}
$$


where

$$
\begin{aligned}
& a=\text { quantity of gas permeating the barrier }\left(\mathrm{cm}^{3}\right. \text { at STP) } \\
& k=\text { solubility constant of the gas-metal system } \\
& D=\text { diffusion constant }\left(\mathrm{cm}^{2} / \mathrm{hr}\right) \\
& A=\text { area of barrier } \\
& \mathrm{p}_{1}=\text { pressure on one face of barrier (atm) } \\
& \mathrm{P}_{2}=\text { pressure on other face (atm) } \\
& \mathrm{E}_{\mathrm{p}}=\text { activation energy of permeation (cal/g-atom) } \\
& \mathbf{x}=\text { thickness of barrier (mm) } \\
& T=\text { absolute temperature }\left({ }^{\circ} \mathrm{K}\right) \\
& t=\text { time in hours } \\
& R=\text { gas constant }
\end{aligned}
$$

In this study, the downstream face was kept at vacuum so that $\mathrm{p}_{2}=0$ es sentially. The permeation equation may then be written as

$$
J=\frac{C_{p}^{1 / 2}}{x} e^{-E_{p} / R T}
$$

where

$$
\begin{aligned}
J & =f l u x[a / A t] \\
C & =a \text { constant }[k D] .
\end{aligned}
$$

For the case of the permeation of a glass-ceramic barrier, slightly modified forms of Equations 2 and 3 must be used. In this case, the exponent of $p$ is not necessarily 1/2. In some cases it is 1 , and in others it is a fraction. It must be determined experimentally from the slope of a ln J vs $\ln$ p plot at constant temperature.

\section{CHIEF FACTORS AFFECTING PERMEATION}

As is apparent from Equation 3, the chief factors affecting the flux through a membrane are pressure, temperature, and membrane thickness. The nature

$$
\text { NAA-SR-6109 }
$$


of the dependence of these variables demanded by Equation 3 can be readily verified by controlled experiments. For example, at constant temperature the slope of a $\ln \mathrm{J}$ vs $\ln \mathrm{p}$ plot verifies the exponent of $\mathrm{p}$. Likewise, for a family of data at constant pressure, a plot of $\ln \mathrm{J}$ vs $1 / \mathrm{T}$ should yield a straight line who se slope is $E_{P} / R$. Finally, under conditions of constant pressure and temperature, but with membranes of varying thicknesses, a plot of $\mathrm{J} \mathrm{vs} 1 / \mathrm{x}$ should yield a straight line.

\section{E. MISCELLANEOUS FACTORS AFFECTING PERMEATION}

1. Effect of Alloying

It would be expected that alloying with a more permeable element would increase the overall rate of permeation of a given material. It has been observed by Baukloh and Kayser ${ }^{9}$ that increasing the percentage of nickel in the alloy system of nickel-copper leads to an increase in overall permeability. Their measurements are in the range of from 20 to $63 \%$ nickel and show a difference in character, depending on the temperature at which the observations were made.

\section{Effect of Surface Conditions}

As mentioned earlier, it is believed that adsorption must take place before passage of hydrogen into the body of the metal can ensue. Smithells and Ransley ${ }^{2}$ have found that an etched iron membrane will exhibit up to ten times the permeability of a polished membrane. Many metals when studied by normal permeation methods will show a diminution in permeation rate with time, due to trace amounts of oxygen in the hydrogen stream. This effect has been noticed by the authors in the case of stainless steel containing appreciable chromium content. The effect has also been noticed by Flint. ${ }^{10}$ It has also been observed at these laboratories that in the case of Inconel, surface conditions are so important as to be rate determining. Smithels and Ransley ${ }^{15}$ have observed that the low permeability of aluminum to hydrogen is due to the accumulation on the surface of an oxide layer which subsequently prevents the diffusion of hydrogen into the metal.

Braaten and Clark ${ }^{11}$ have found that the rate of diffusion of hydrogen through glass is only slightly altered by roughening the outgoing surface. 


\section{EXPERIMENTAL PROCEDURE}

\section{A. APPARATUS USED IN PREVIOUS INVESTIGATIONS}

A wide variety of apparatus has been used by other investigators; and two distinct devices, by the se laboratories. Generally, the apparatus falls into two categories: cylindrical membrane, and flat disc. Both types possess advantages and disadvantages; none is consistently and completely satisfactory. The authors feel that the nature of the metal with regard to assembly properties should determine the choice of configuration. If the metal is obtained in sheat form, it can be mounted as a membrane in a steel tube, as shown in Figure la. The advantage of this form is that it is possible to maintain the membrane at a uniform temperature over its entire area. The disadvantages of this configuration are threefold. First, the welds are in the hot zone and may well develop leaks when the temperature and pressure conditions are changed. Second, the welds contact the membrane itself and there is the possibility of the welding material diffusing into the membrane, changing its composition. Third, if the steel walls are thin, approaching the thinness of the membrane, or if the permeability rate of the membrane is much lower than that of the steel, hydrogen will be lost from the steel walls, which may result in adsorption on the opposite face of the membrane.

This type of apparatus was used by Johnson and Larose, ${ }^{16}$ Lombard, ${ }^{6}$ and Ham. ${ }^{17}$

A cylindrical device was used by Smithells and Ransley which overcomes many of the previously mentioned disadvantages. Their apparatus is shown in Figure $1 \mathrm{~b}$. It has the advantage of having no welds in the hot zone. Also, the gas pressure is on the outside of the tube. It suffers the disadvartage of having a temperature gradient along the tube. This can at least be estimated by use of an exploring thermocouple. However, this effect must be well compensated since, due to many cooler reactions, it may lead to lower magnitudes of observed rate. Another cylindrical device which was used at one time by the se laboratories $^{18}$ is shown in Figure 1c. This apparatus has the advantage of having no welds in the hot zone. The disadvantages of this device are: first, that the thermal gradient is uncompensated; and second, that the rate is deter mined by the decrease in pressure on the upstream side, which is less precise than by measuring the increase of pressure on the downstream (low pressure) side. This type of apparatus was used by Richardson. ${ }^{19}$ Still another cylindrical device is shown in Figure 1d. The disadvantages of this device are: first, 

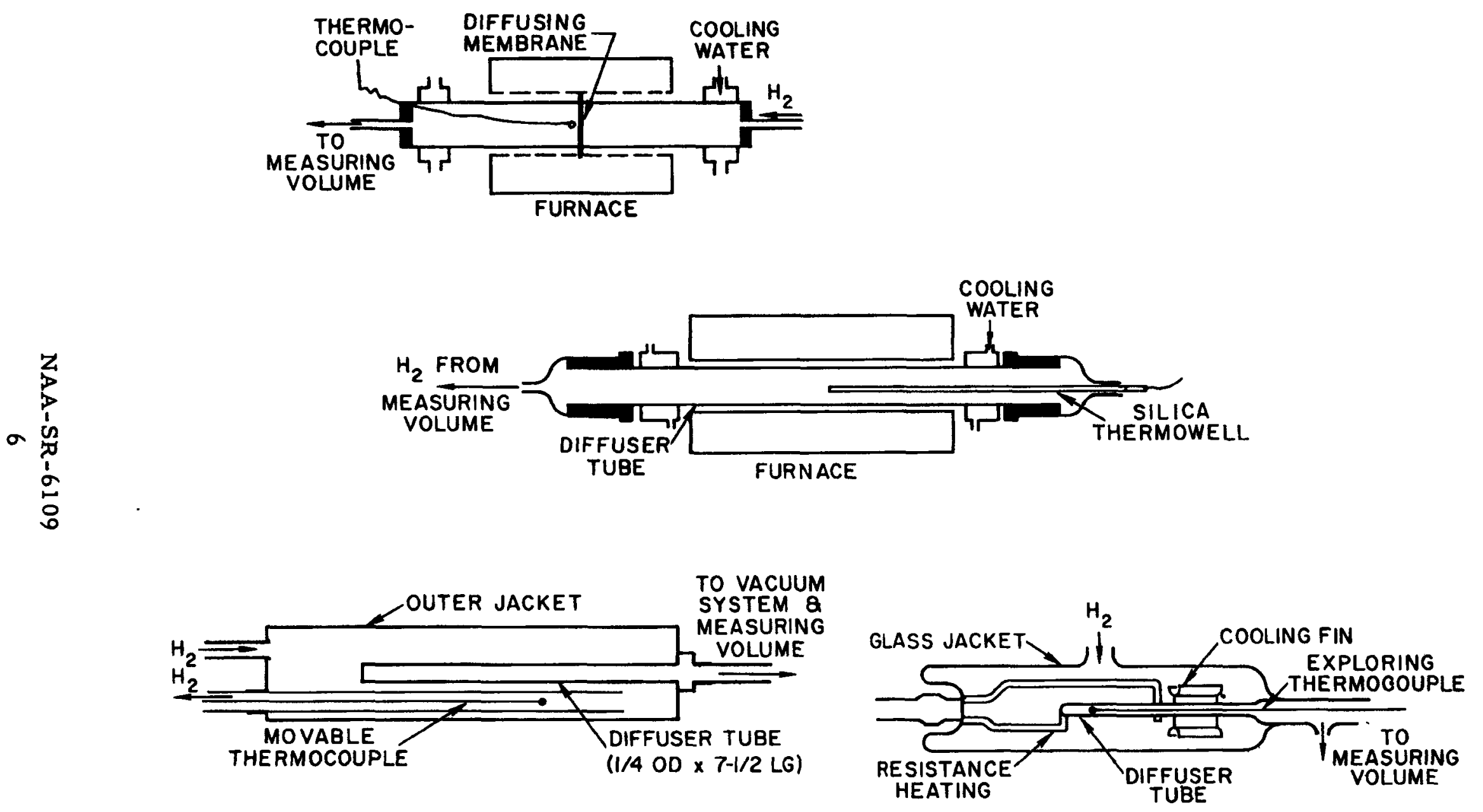

Figure 1. Diffusion Apparatus of Other Investigators 
that the weld is in the hot zone, although the experimenter claims no difficulty in this regard; and second, that the diffusion rate cannot be measured by determining pressure drop, since hydrogen loss through the jacket is high. The device is equipped with a movable thermocouple. This apparatus was used by Flint. 14

\section{B. APPARATUS USED IN THESE INVESTIGATIONS}

The apparatus used in the se experiments is shown schematically in Figures 2 and 3, and photographed in Figure 4. The membrane is a thin disc, which is

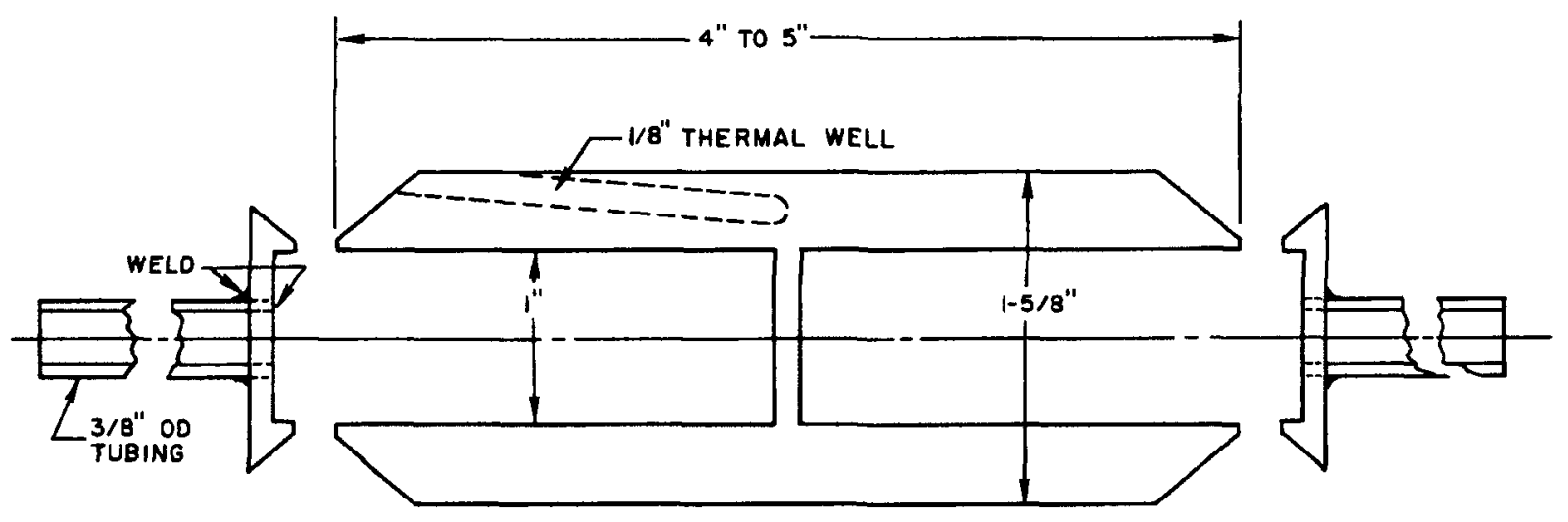

Figure 2. Detail of the Membrane

integral to an entire membrane assembly. This unit is of one piece, machined from a solid ingot of metal stock. When finished, the membrane is usually about 5 in. long. The diameter of the disc is about 1 in. wide, at variousthicknesses from $1 / 32$ to $1 / 8$ in. The wall thickness is large compared to the thickness of the membrane. Figure 4 is a photograph of the diffusion membrane. This design makes it possible for some gas to diffuse around the corner section of the disc where it joins the walls of the assembly. It is felt, however, that if this effect is present, the order of magnitude is small, as evidenced by the constancy of the values of specific rate where membranes of different thicknesses have been tested. A thermocouple well is drilled to the vicinity of the membrane itself. The advantages of this configuration are: (1) no welds exist about the membrane itself, so that there is small probability of membrane contamination 

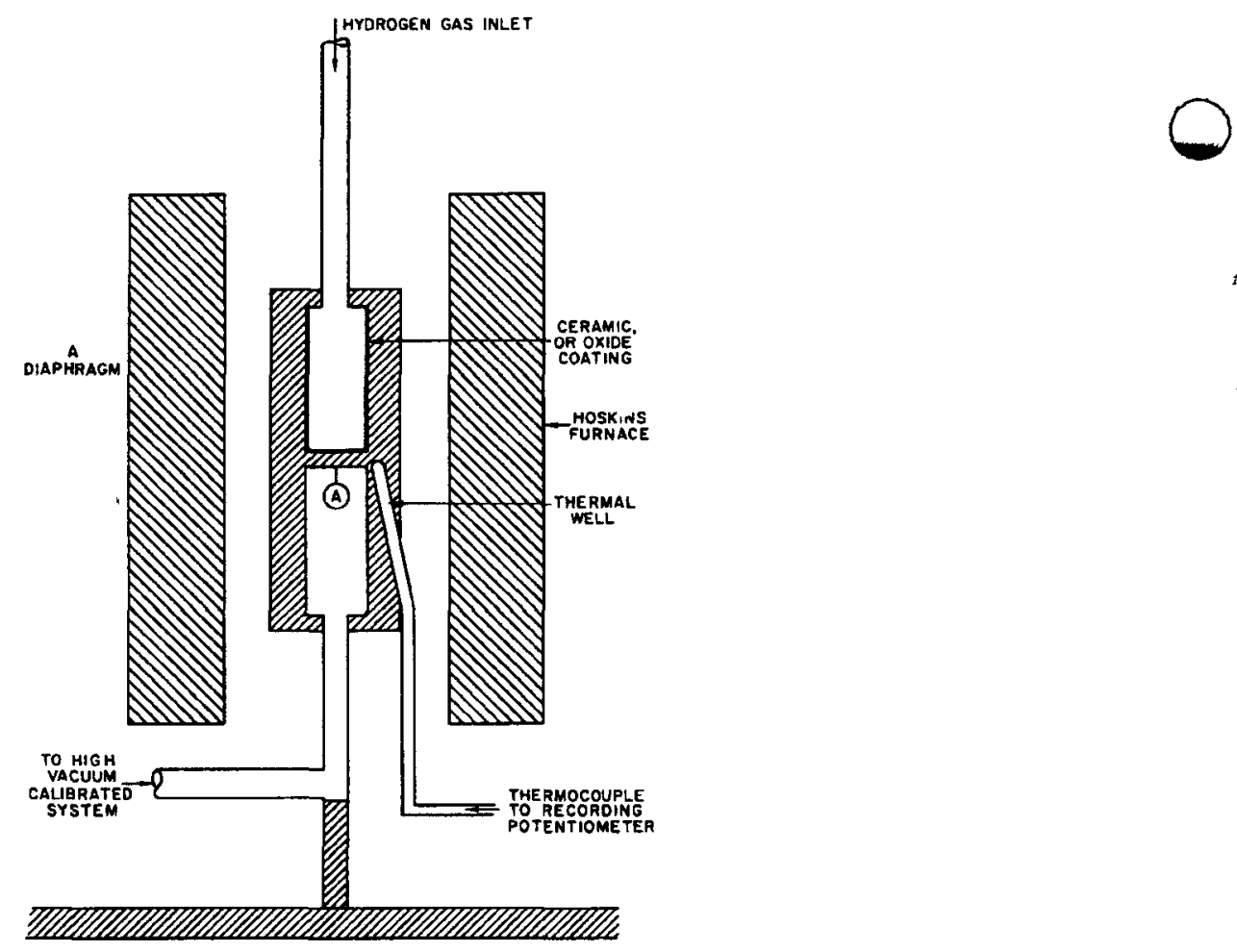

Figure 3. Cross Section of

Furnace Assembly

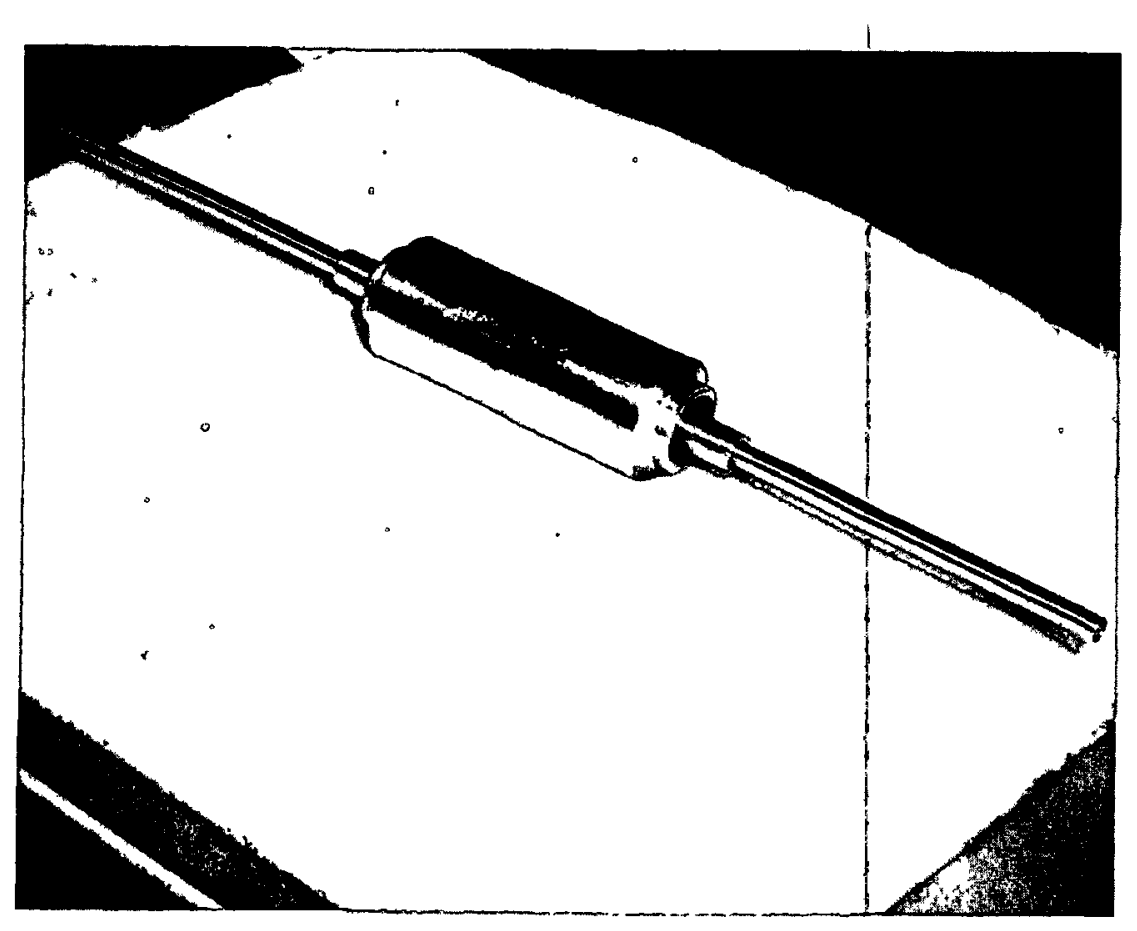

Figure 4. Assembled Diffusion Membrane

NAA-SR-6109 
from welding material; (2) the membrane assembly can be maintained at a constant temperature; (3) it is possible to reproduce the results by using different specimens. The only disadvantage of the device is that the welds are in the hot zone, and this can be eliminated by making the membrane assembly long. Thus, the advantages of the device far outshadow the disadvantages.

A schematic diagram of the gas train is shown in Figure 5. The gas leaving the downstream side of the membrane is conveyed by Toepler pump to a calibrated volume. Between pump and membrane assembly is a cold trap to prevent migration of mercury vapor to the downstream membrane face. This trap contains a dry ice-acetone mixture for the metal systems, and liquid nitrogen for the glass-metal systems. Figure 5 also shows the upstream section. Tank hydrogen is fed successively through a catalytic "de-oxo" getter, a 3-ft tower of calcium hydride; and finally through a 12-in. column of titanium hydride maintained at about $1000^{\circ} \mathrm{C}$. From here, the gas diffuses through a palladium coil and fills the upstream side of the membrane assembly. The pressure is allowed to build up to an excess, which is then bled off to a long column of mercury. By raising or lowering this column, the pressure may be maintained to a very precise degree. This downstream setup is quite standard, being essentially the same as those used by other investigators. One thing may be mentioned. When observing small gas volumes $\left(10^{-3} \mathrm{~cm}^{3} \mathrm{hr}{ }^{-1}\right)$, the accuracy of the se determinations may be greatly increased by the use of a multirange McLeod gauge, which serves as both the calibrated collection volume and the pressure measuring device. Figure 6 shows the entire downstream line equipped with $a$ multirange McLeod gauge, with the exception of mercury pressure regulators. Figure 7 shows a setup equipped with an ordinary calibrated volume. 


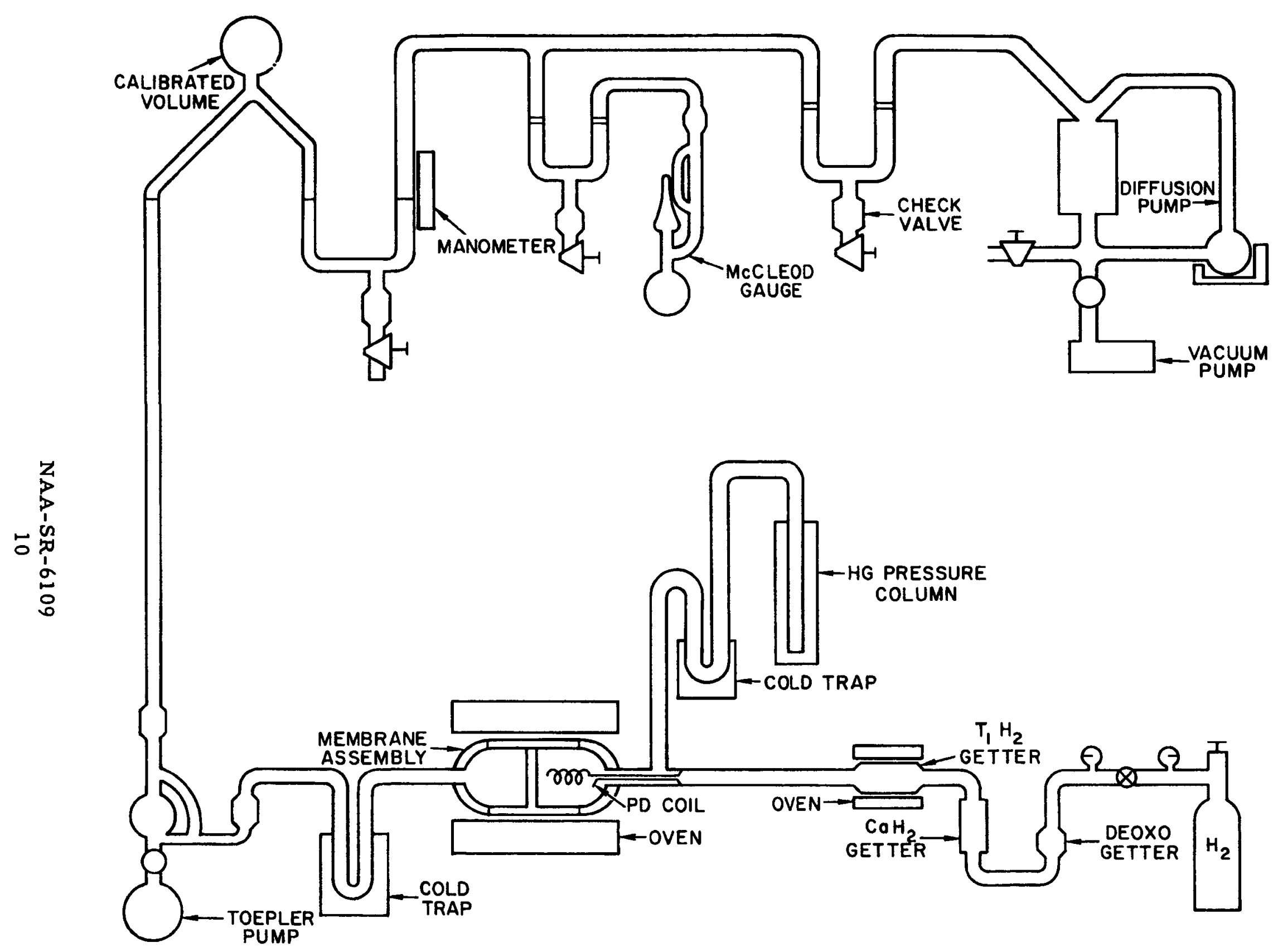

Figure 5. Diffusion System 


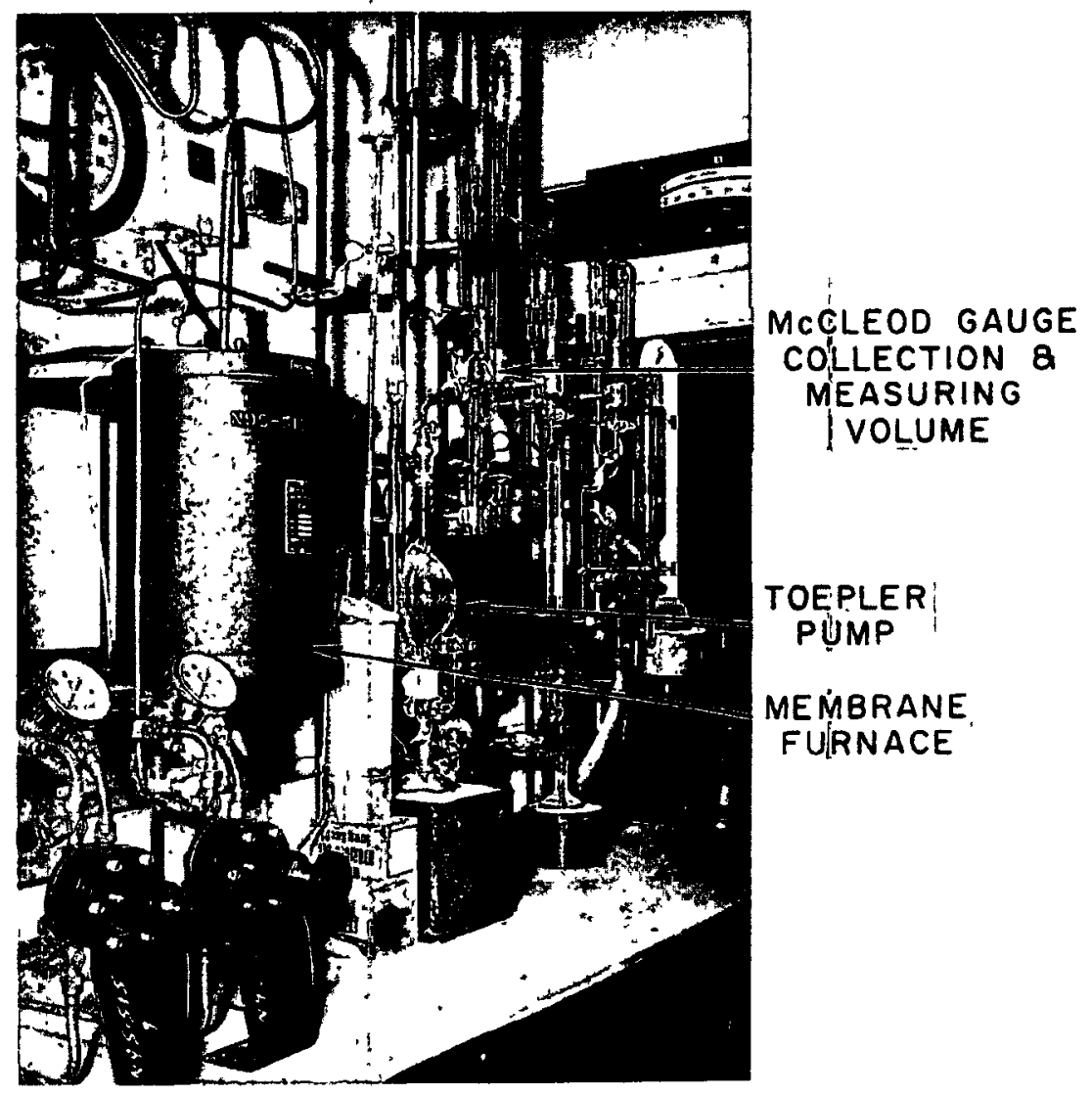

Figure 6. Membrane Furnace and Downstream Collection Line 


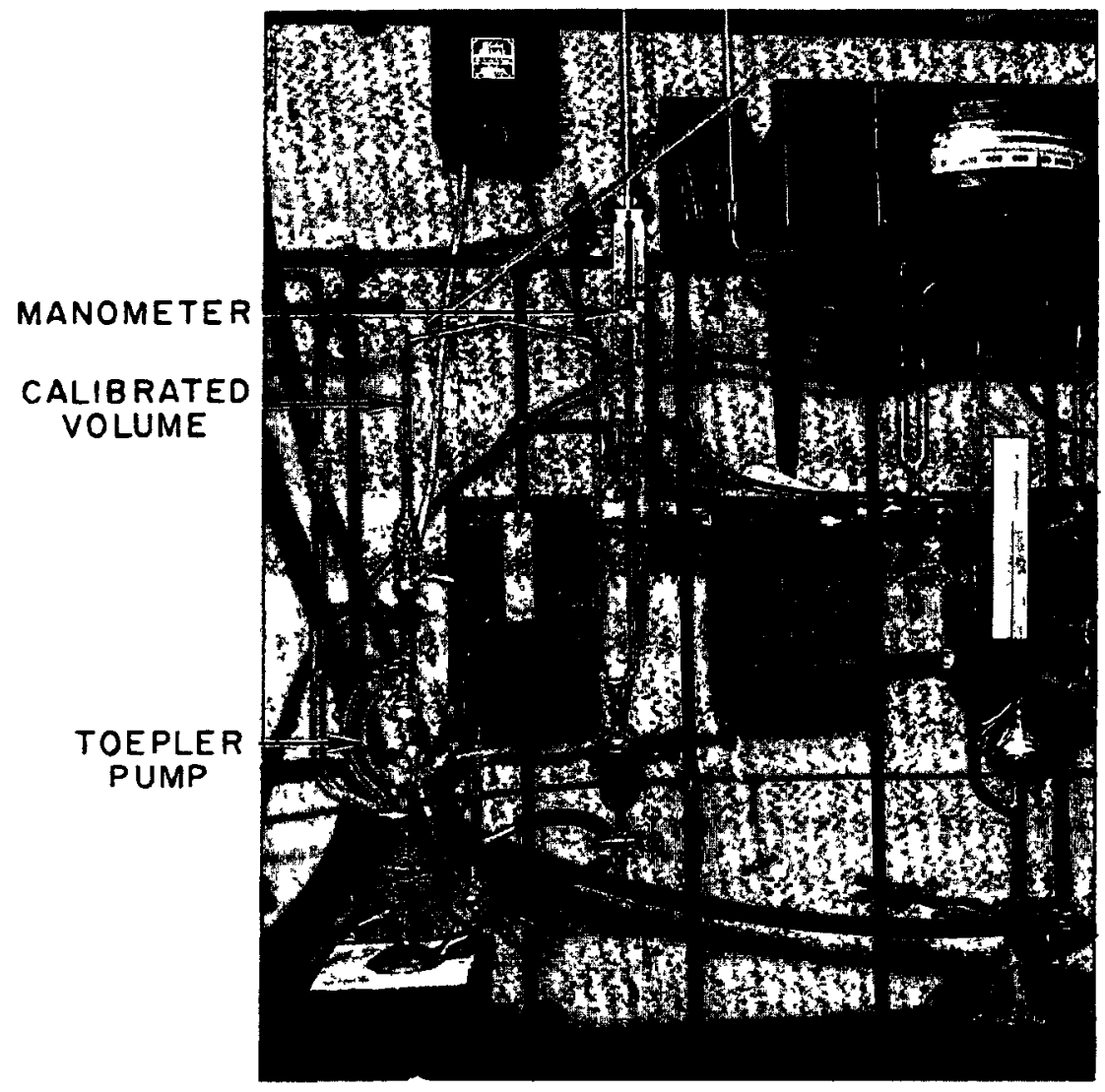

Figure 7. Ordinary Manometer Collection and Measuring Volume 


\section{PERMEABILITY OF AISI-TYPE 430 STAINLESS STEEL TO HYDROGEN}

\section{A. MATERIAL}

Vacuum-cast AISI-Type 430 stainless steel was obtained from National Research Co., Cambridge, Mass. These ingots were forged after casting. The material was determined to be pore-free by $x$-ray analysis. Chemical analysis of the material is as follows:

$$
\begin{array}{lr}
\text { Cr } & 15.61 \% \\
\text { Si } & 0.01 \% \\
\text { Mn } & \text { N. D. } \\
\text { C } & 0.04 \% \\
\text { Fe } & \text { Bal. }
\end{array}
$$

\begin{tabular}{|c|c|c|}
\hline $\begin{array}{c}\text { Membrane } \\
\text { No. } \\
\end{array}$ & $\begin{array}{c}\text { Thickness } \\
\text { (in.) } \\
\end{array}$ & $\begin{array}{c}\text { Diameter } \\
\text { (in.) } \\
\end{array}$ \\
\hline 1 & 0.0608 & 0.9965 \\
\hline 2 & 0.0929 & 0.9965 \\
\hline 3 & 0.1242 & 1.0133 \\
\hline
\end{tabular}

Three membranes were machined with these dimensions:

\section{B. ACCURACY OF MEASUREMENTS}

After the membranes were mounted in the ovens, outgassing was initiated

\begin{tabular}{|c|c|}
\hline $\begin{array}{c}\text { Membrane } \\
\text { No. }\end{array}$ & $\begin{array}{l}\text { Background Error } \\
\left(\mathrm{cc} \text { at } \mathrm{STP} / \mathrm{cm}^{2}-\mathrm{hr}\right)\end{array}$ \\
\hline 1 & 0.00006 \\
\hline 2 & 0.00009 \\
\hline 3 & 0.00012 \\
\hline
\end{tabular}
at $800^{\circ} \mathrm{C}$, and continued for $48 \mathrm{hr}$. At this time, the temperature was lowered to $760^{\circ} \mathrm{C}$ and the calibrated volume arranged for collection. This blank run lasted $24 \mathrm{hr}$. The results were such that the error introduced to the subsequent determinations was the following: 


\section{DATA}

The study was conducted using three membranes of different thicknesses. Permeability rates were determined at 649,704 , and $760^{\circ}$. At each temperature level, the rates were evaluated at $1.1,1.5$, and 2.0 atm hydrogen pressure. These data, listed in Tables I through III, were machine-fitted to Equation 3.

The equations giving the best fit of the data are given at the beginning of each table, and the flux values calculated from the se equations are noted in the final column of each table. It will be noticed that each of the membranes gave different results, indicating the possible presence of flow-inhibiting oxide films. Since membrane No. 3 is the most porous on a unit thickness basis (a fact easily confirmed by multiplying the flux for a given condition by the membrane thickness and comparing the result with another membrane at the same temperature

and pressure), it is presumably the most representative of the true permeability of Type 430 stainless steel. 
TABLE I

RATE OF HYDROGEN PERMEATION THROUGH AISI-TYPE 430 STAINLESS STEEL MEMBRANE NO. 1

\begin{tabular}{|c|c|c|c|c|}
\hline \multirow{2}{*}{$\underset{\left({ }^{\circ} \mathrm{C}\right)}{\text { Temperature }}$} & \multirow{2}{*}{$\begin{array}{l}\text { Pressure } \\
\quad(\text { atm })\end{array}$} & \multirow{2}{*}{$\begin{array}{c}\text { Rate } \\
\text { (cc at STP/hr) }\end{array}$} & \multicolumn{2}{|c|}{$\begin{array}{c}\text { Flux } \\
\left.\text { (cc at STP } / \mathrm{cm}^{2}-\mathrm{hr}\right)\end{array}$} \\
\hline & & & Actual & Calculated \\
\hline \multirow[t]{3}{*}{649} & 1.1 & $\begin{array}{l}2.36 \\
2.37 \\
2.40\end{array}$ & $\begin{array}{l}0.469 \\
0.471 \\
0.477\end{array}$ & 0.472 \\
\hline & 1.5 & $\begin{array}{l}2.74 \\
2.75 \\
2.73\end{array}$ & $\begin{array}{l}0.545 \\
0.547 \\
0.543\end{array}$ & 0.550 \\
\hline & 2.0 & $\begin{array}{l}3.24 \\
3.18 \\
3.20\end{array}$ & $\begin{array}{l}0.644 \\
0.632 \\
0.636\end{array}$ & 0.635 \\
\hline \multirow[t]{3}{*}{704} & 1.1 & $\begin{array}{l}3.37 \\
3.35 \\
3.32\end{array}$ & $\begin{array}{l}0.670 \\
0.666 \\
0.660\end{array}$ & 0.660 \\
\hline & 1.5 & $\begin{array}{l}3.87 \\
3.92 \\
3.93\end{array}$ & $\begin{array}{l}0.769 \\
0.779 \\
0.781\end{array}$ & 0.770 \\
\hline & 2.0 & $\begin{array}{l}4.49 \\
4.42 \\
4.44\end{array}$ & $\begin{array}{l}0.892 \\
0.878 \\
0.882\end{array}$ & 0.890 \\
\hline \multirow[t]{3}{*}{760} & 1.1 & $\begin{array}{l}4.47 \\
4.73 \\
4.63 \\
4.52\end{array}$ & $\begin{array}{l}0.888 \\
0.940 \\
0.920 \\
0.898\end{array}$ & 0.891 \\
\hline & 1.5 & $\begin{array}{l}5.10 \\
5.17 \\
5.26 \\
5.19\end{array}$ & $\begin{array}{l}1.014 \\
1.028 \\
1.045 \\
1.032\end{array}$ & 1.040 \\
\hline & 2.0 & $\begin{array}{l}5.95 \\
5.95 \\
5.96 \\
5.92 \\
\end{array}$ & $\begin{array}{l}1.183 \\
1.183 \\
1.185 \\
1.177 \\
\end{array}$ & 1.201 \\
\hline
\end{tabular}

NAA-SR-6109 
TABLE II

RATE OF HYDROGEN PERMEATION THROUGH AISI-TYPE 430 STAINLESS STEEL MEMBRANE NO. 2

$$
\left(J=\frac{394 p^{1 / 2}}{x} e^{-11,326 / R T}\right)
$$

\begin{tabular}{|c|c|c|c|c|}
\hline \multirow{2}{*}{$\begin{array}{c}\text { Temperature } \\
\left({ }^{\circ} \mathrm{C}\right)\end{array}$} & \multirow{2}{*}{$\begin{array}{l}\text { Pressure } \\
\text { (atm) }\end{array}$} & \multirow{2}{*}{$\begin{array}{c}\text { Rate } \\
\text { (cc at STP/hr) }\end{array}$} & \multicolumn{2}{|c|}{$\begin{array}{c}\text { Flux } \\
\left(\mathrm{cc} \text { at } \mathrm{STP} / \mathrm{cm}^{2}-\mathrm{hr}\right)\end{array}$} \\
\hline & & & Actual & Calculated \\
\hline \multirow[t]{3}{*}{649} & 1.1 & $\begin{array}{l}1.83 \\
1.81 \\
1.85\end{array}$ & $\begin{array}{l}0.364 \\
0.360 \\
0.368\end{array}$ & 0.362 \\
\hline & 1.5 & $\begin{array}{l}2.13 \\
2.13 \\
2.10\end{array}$ & $\begin{array}{l}0.423 \\
0.423 \\
0.417\end{array}$ & 0.423 \\
\hline & 2.0 & $\begin{array}{l}2.43 \\
2.46 \\
2.49\end{array}$ & $\begin{array}{l}0.483 \\
0.489 \\
0.495\end{array}$ & 0.489 \\
\hline \multirow[t]{3}{*}{704} & 1.1 & $\begin{array}{l}2.60 \\
2.59 \\
2.57\end{array}$ & $\begin{array}{l}0.517 \\
0.515 \\
0.511\end{array}$ & 0.515 \\
\hline & 1.5 & $\begin{array}{l}3.00 \\
3.03 \\
3.05\end{array}$ & $\begin{array}{l}0.596 \\
0.602 \\
0.606\end{array}$ & 0.601 \\
\hline & 2.0 & $\begin{array}{l}3.52 \\
3.52 \\
3.45\end{array}$ & $\begin{array}{l}0.700 \\
0.700 \\
0.686\end{array}$ & 0.694 \\
\hline \multirow[t]{3}{*}{760} & 1.1 & $\begin{array}{l}3.50 \\
3.48 \\
3.44\end{array}$ & $\begin{array}{l}0.696 \\
0.692 \\
0.684\end{array}$ & 0.704 \\
\hline & 1.5 & $\begin{array}{l}4.21 \\
4.19 \\
4.21\end{array}$ & $\begin{array}{l}0.837 \\
0.833 \\
0.837\end{array}$ & 0.823 \\
\hline & 2.0 & $\begin{array}{l}4.81 \\
4.81 \\
4.79 \\
\end{array}$ & $\begin{array}{l}0.956 \\
0.956 \\
0.952 \\
\end{array}$ & 0.950 \\
\hline
\end{tabular}


TABLE III

RATE OF HYDROGEN PERMEATION THROUGH AISI-TYPE 430

STAINLESS STEEL MEMBRANE NO. 3

\begin{tabular}{|c|c|c|c|c|}
\hline \multirow{2}{*}{$\begin{array}{l}\text { Temperature } \\
\left({ }^{\circ} \mathrm{C}\right)\end{array}$} & \multirow{2}{*}{$\begin{array}{l}\text { Pressure } \\
\text { (atm) }\end{array}$} & \multirow{2}{*}{$\begin{array}{c}\text { Rate } \\
\text { (cc at STP/hr) }\end{array}$} & \multicolumn{2}{|c|}{$\begin{array}{c}\text { Flux } \\
\text { (cc at STP/cm } \\
\text { STr) }\end{array}$} \\
\hline & & & Actual & Calculated \\
\hline \multirow[t]{3}{*}{649} & 1.1 & $\begin{array}{l}1.45 \\
1.46 \\
1.46\end{array}$ & $\begin{array}{l}0.268 \\
0.270 \\
0.270\end{array}$ & 0.271 \\
\hline & 1.5 & $\begin{array}{l}1.70 \\
1.71 \\
1.76\end{array}$ & $\begin{array}{l}0.314 \\
0.316 \\
0.326\end{array}$ & 0.316 \\
\hline & 2.0 & $\begin{array}{l}1.96 \\
1.98 \\
1.99\end{array}$ & $\begin{array}{l}0.363 \\
0.366 \\
0.368\end{array}$ & 0.365 \\
\hline \multirow[t]{3}{*}{704} & 1.1 & $\begin{array}{l}2.04 \\
2.07 \\
2.08\end{array}$ & $\begin{array}{l}0.377 \\
0.383 \\
0.385\end{array}$ & 0.386 \\
\hline & 1.5 & $\begin{array}{l}2.46 \\
2.44 \\
2.40\end{array}$ & $\begin{array}{l}0.455 \\
0.451 \\
0.444\end{array}$ & 0.451 \\
\hline & 2.0 & $\begin{array}{l}2.80 \\
2.81 \\
2.85\end{array}$ & $\begin{array}{l}0.518 \\
0.520 \\
0.527\end{array}$ & 0.520 \\
\hline \multirow[t]{3}{*}{760} & 1.1 & $\begin{array}{l}2.85 \\
2.81 \\
2.84\end{array}$ & $\begin{array}{l}0.527 \\
0.520 \\
0.525\end{array}$ & 0.530 \\
\hline & 1.5 & $\begin{array}{l}3.33 \\
3.33 \\
3.32\end{array}$ & $\begin{array}{l}0.616 \\
0.616 \\
0.614\end{array}$ & 0.619 \\
\hline & 2.0 & $\begin{array}{l}3.95 \\
3.95 \\
3.94\end{array}$ & $\begin{array}{l}0.731 \\
0.731 \\
0.729\end{array}$ & 0.714 \\
\hline
\end{tabular}




\section{PERMEABILITY OF AISI-TYPE 321 STAINLESS STEEL TO HYDROGEN}

\section{A. MATERIAL}

Vacuum cast AISI-Type 321 stainless steel ingot was obtained from National Research Co., Cambridge, Mass. This ingot was also forged after casting. Chemical analysis was reported as:

$\begin{array}{ll}\text { Cr } & 17.93 \% \\ \mathrm{Si} & 0.01 \% \\ \mathrm{Mn} & 0.33 \% \\ \mathrm{C} & 0.036 \% \\ \mathrm{Ti} & 0.37 \% \\ \mathrm{Ni} & 19.38 \% \\ \mathrm{Fe} & \mathrm{Bal} .\end{array}$

After the ingot was found to be pore-free by $x$-ray analysis, one diaphragm was machined to the following dimensions:

Thickness $=0.1230 \mathrm{in}$.

Diameter $=1.0054 \mathrm{in}$.

\section{B. ACCURACY OF MEASUREMENTS}

Outgassing of this sample was accomplished in exactly the same manner as with the AISI-Type 430 stainless steel samples. The results of the blank-run determination are such that the error due to leakage of the system is less than $0.015 \mathrm{cc}$ at $\mathrm{STP} / \mathrm{cm}^{2}-\mathrm{hr}$.

\section{DATA}

The data, which are summarized in Table IV, were machine fitted to Equation 3; and the resulting constants will be found in the equation at the head of Table TV.

It is of interest to compare these data with those of Flint's. ${ }^{14}$ Table V show 8 three value 8 determined by Flint with a 0.034 -in. thick membrane. The values calculated from the equation at the head of Table IV are included for comparison. The agreement is quite good for investigations of this type. 
TABLE IV

RATE OF HYDROGEN PERMEATION THROUGH AISI-TYPE 321 ST AINLESS STEEL

\begin{tabular}{|c|c|c|c|c|}
\hline \multirow{2}{*}{$\begin{array}{l}\text { Temperature } \\
\left({ }^{\circ} \mathrm{C}\right)\end{array}$} & \multirow{2}{*}{$\begin{array}{l}\text { Pressure } \\
\text { (atm) }\end{array}$} & \multirow{2}{*}{$\begin{array}{c}\text { Rate } \\
\text { (cc at STP/hr) }\end{array}$} & \multicolumn{2}{|c|}{$\begin{array}{c}\text { Flux } \\
\text { (cc at STP } / \mathrm{cm}^{2}-\mathrm{hr} \text { ) }\end{array}$} \\
\hline & & & Actual & Calculated \\
\hline \multirow[t]{3}{*}{649} & 1.1 & $\begin{array}{l}0.407 \\
0.412 \\
0.416\end{array}$ & $\begin{array}{l}0.0795 \\
0.0804 \\
0.0812\end{array}$ & 0.0792 \\
\hline & 1.5 & $\begin{array}{l}0.461 \\
0.465 \\
0.462\end{array}$ & $\begin{array}{l}0.0900 \\
0.0908 \\
0.0902\end{array}$ & 0.0925 \\
\hline & 2.0 & $\begin{array}{l}0.532 \\
0.529 \\
0.528\end{array}$ & $\begin{array}{l}0.104 \\
0.103 \\
0.103\end{array}$ & 0.1069 \\
\hline \multirow[t]{3}{*}{704} & 1.1 & $\begin{array}{l}0.676 \\
0.654 \\
0.699\end{array}$ & $\begin{array}{l}0.132 \\
0.128 \\
0.137\end{array}$ & 0.130 \\
\hline & 1.5 & $\begin{array}{l}0.787 \\
0.816 \\
0.797\end{array}$ & $\begin{array}{l}0.154 \\
0.159 \\
0.156\end{array}$ & 0.152 \\
\hline & 2.0 & $\begin{array}{l}0.950 \\
0.938 \\
0.972\end{array}$ & $\begin{array}{l}0.186 \\
0.183 \\
0.190\end{array}$ & 0.176 \\
\hline \multirow[t]{3}{*}{760} & 1.1 & $\begin{array}{l}1.04 \\
1.03 \\
1.02\end{array}$ & $\begin{array}{l}0.203 \\
0.201 \\
0.199\end{array}$ & 0.204 \\
\hline & 1.5 & $\begin{array}{l}1.19 \\
1.20\end{array}$ & $\begin{array}{l}0.232 \\
0.234\end{array}$ & 0.238 \\
\hline & 2.0 & $\begin{array}{l}1.35 \\
1.38 \\
1.39\end{array}$ & $\begin{array}{l}0.264 \\
0.269 \\
0.271\end{array}$ & 0.275 \\
\hline
\end{tabular}


TABLE V

PERMEABILITY OF AISI-TYPE 321 STAINLESS STEEL TO HYDROGEN AT ONE ATMOSPHERE

\begin{tabular}{c|c|c}
\hline \multirow{2}{*}{$\begin{array}{c}\text { Temperature } \\
\left({ }^{\circ} \mathrm{C}\right)\end{array}$} & \multicolumn{2}{|c}{$\begin{array}{c}\text { Permeability } \\
\text { (cc at STP-mm/cm }-\mathrm{hr} \text { ) }\end{array}$} \\
\cline { 2 - 3 } & Flint 14 & This Work \\
\hline 386 & 0.0076 & 0.0072 \\
590 & 0.120 & 0.132 \\
792 & 0.70 & 0.78 \\
\hline
\end{tabular}

NAA-SR-6109 


\section{PERMEABILITY OF CALORIZED AISI TYPE 430 STAINLESS STEEL TO HYDROGEN}

\section{A. MATERIAL}

The three AISI Type 430 stainless steel membranes previously discussed were calorized by the Calorizing Co., Wilkinsburg Station, Pittsburgh, Pa. Calorizing is a process for applying an aluminum coating on steel or other ferous alloys. The coating consists mainly of an aluminum-iron intermetallic compound with a superficial film of aluminum oxide at the outer surface. Since the vendor states the coating is stable above the melting point of aluminum, the membranes were outgassed at $760^{\circ} \mathrm{C}$ and later tested at 590 to $650^{\circ} \mathrm{C}$. The three membranes in finished form were:

\begin{tabular}{ccc} 
Membrane & $\begin{array}{c}\text { Metal Dimensions } \\
\text { (in.) }\end{array}$ & $\begin{array}{c}\text { Calorizing } \\
\text { Thickness } \\
\text { (in.) }\end{array}$ \\
\hline 1 & $\begin{array}{l}\text { Diameter }=0.9965 \\
\text { Thickness }=0.0929\end{array}$ & 0.015 \\
2 & $\begin{array}{l}\text { Diameter }=1.033 \\
\text { Thickness }=0.1242\end{array}$ & 0.010 \\
3 & $\begin{array}{l}\text { Diameter }=0.9965 \\
\text { Thickness }=0.0608\end{array}$ & 0.040
\end{tabular}

\section{B. ACCURACY OF MEASUREMENTS}

The three membranes were outgassed at $760^{\circ} \mathrm{C}$ for seven days. The temperature was then lowered to $650^{\circ}$ and a blank run started, which lasted for a total of 18 days. The results of the blank runs are such that:

$\begin{array}{cc}\text { Membrane } & \begin{array}{c}\text { Background } \\ \text { (cc at STP/ } / \mathrm{cm}^{2}-\mathrm{hr} \text { ) }\end{array} \\ 1 & 0.00010 \\ 2 & 0.00001 \\ 3 & 0.00010\end{array}$

\section{DATA}

The data are listed in Tables VI through XI. No attempt was made to fit the data to the form of Equation 3, since it was apparent that both the temperature and pressure dependence were very unpredictable. For example, the 
TABLE VI

RATE OF HYDROGEN PERMEATION THROUGH CALORIZED AISI-TYPE 430 STAINLESS STEEL MEMBRANE NO. 1

\begin{tabular}{|c|c|c|c|}
\hline $\begin{array}{l}\text { Temperature } \\
\left({ }^{\circ} \mathrm{C}\right)\end{array}$ & $\begin{array}{l}\text { Pressure } \\
\text { (atm) }\end{array}$ & $\begin{array}{c}\text { Rate } \\
\text { (cc at STP/hr) }\end{array}$ & $\underset{\text { (cc at STP } / \mathrm{cm}^{2}-\mathrm{hr} \text { ) }}{\operatorname{Flux}}$ \\
\hline \multirow[t]{3}{*}{550} & 1.1 & $\begin{array}{l}0.041 \\
0.043 \\
0.035 \\
0.035 \\
0.038\end{array}$ & $\begin{array}{l}0.008 \\
0.009 \\
0.007 \\
0.007 \\
0.007\end{array}$ \\
\hline & 1.5 & $\begin{array}{l}0.036 \\
0.036 \\
0.040 \\
0.037\end{array}$ & $\begin{array}{l}0.007 \\
0.007 \\
0.008 \\
0.007\end{array}$ \\
\hline & 2.0 & $\begin{array}{l}0.032 \\
0.038 \\
0.035\end{array}$ & $\begin{array}{l}0.006 \\
0.007 \\
0.007\end{array}$ \\
\hline \multirow[t]{3}{*}{590} & 1.1 & $\begin{array}{l}0.034 \\
0.034 \\
0.033 \\
0.033 \\
0.033\end{array}$ & $\begin{array}{l}0.007 \\
0.007 \\
0.007 \\
0.007 \\
0.007\end{array}$ \\
\hline & 1.5 & $\begin{array}{l}0.049 \\
0.044 \\
0.039 \\
0.043\end{array}$ & $\begin{array}{l}0.009 \\
0.009 \\
0.008 \\
0.009\end{array}$ \\
\hline & 2.0 & $\begin{array}{l}0.062 \\
0.060 \\
0.058 \\
0.057 \\
0.053 \\
0.053 \\
0.050 \\
0.051 \\
0.064\end{array}$ & $\begin{array}{l}0.013 \\
0.012 \\
0.012 \\
0.011 \\
0.011 \\
0.011 \\
0.010 \\
0.010 \\
0.013\end{array}$ \\
\hline \multirow[t]{3}{*}{650} & 1.1 & $\begin{array}{l}0.107 \\
0.106 \\
0.105\end{array}$ & $\begin{array}{l}0.021 \\
0.021 \\
0.021\end{array}$ \\
\hline & 1.5 & $\begin{array}{l}0.109 \\
0.120 \\
0.120\end{array}$ & $\begin{array}{l}0.023 \\
0.023 \\
0.023\end{array}$ \\
\hline & 2.0 & $\begin{array}{l}0.124 \\
0.129 \\
0.131\end{array}$ & $\begin{array}{l}0.024 \\
0.026 \\
0.026\end{array}$ \\
\hline
\end{tabular}

NAA-SR-6109 
TABLE VII

SUMMARY OF DATA FOR RATE OF HYDROGEN PERMEATION THROUGH CALORIZED AISI-TYPE 430 STAINLESS STEEL MEMBRANE NO. 1

\begin{tabular}{c|c|c|c}
\hline $\begin{array}{c}\text { Temperature } \\
\left({ }^{\circ} \mathrm{C}\right)\end{array}$ & $\begin{array}{c}\text { Pressure } \\
\text { (atm) }\end{array}$ & $\begin{array}{c}\text { Rate } \\
\text { (cc at STP/hr) }\end{array}$ & $\begin{array}{c}\text { Flux } \\
\text { (cc at STP/cm } \text { athr) }^{2}\end{array}$ \\
\hline \multirow{2}{5}{550} & 1.1 & 0.038 & 0.007 \\
& 1.5 & 0.037 & 0.007 \\
& 2.0 & 0.035 & 0.007 \\
\hline \multirow{2}{*}{590} & 1.1 & 0.033 & 0.007 \\
& 1.5 & 0.044 & 0.009 \\
& 2.0 & 0.057 & 0.011 \\
\hline \multirow{2}{*}{650} & 1.1 & 0.106 & 0.021 \\
& 1.5 & 0.120 & 0.023 \\
& 2.0 & 0.128 & 0.025 \\
\hline
\end{tabular}

permeability of membrane No. 1 was apparently independent of pressure at $550^{\circ} \mathrm{C}$ (Table VII); and the permeability of membrane No. 2 surprisingly decreased as the temperature was raised from 550 to $590^{\circ} \mathrm{C}$ (Table IX). It is significant, however, that the calorized coatings lowered the permeability of the membranes by one to two orders of magnitude (see data on uncoated AISI-Type 430 stainless steel).

Figure 8 shows the structure of a calorized coating (approximately 0.030 in.) on mild steel. It is evident from this photomicrograph that the surface of the coating is quite porous, presumably because of a relatively high $\mathrm{Al}_{2} \mathrm{O}_{3}$ content. The coatings after testing are shown in Figures 9 and 10 . What was originally a 10 to $15-\mathrm{mil}$ coating is now only 2 to 3 mils thick because of the diffusion of the Al inward during the testing. This variation in surface of the membrane with time probably accounts for the inconsistencies in the test data. 
TABLE VIII

RATE OF HYDROGEN PERMEATION THROUGH CALORIZED AISI-TYPE 430 STAINLESS STEEL MEMBRANE NO. 2

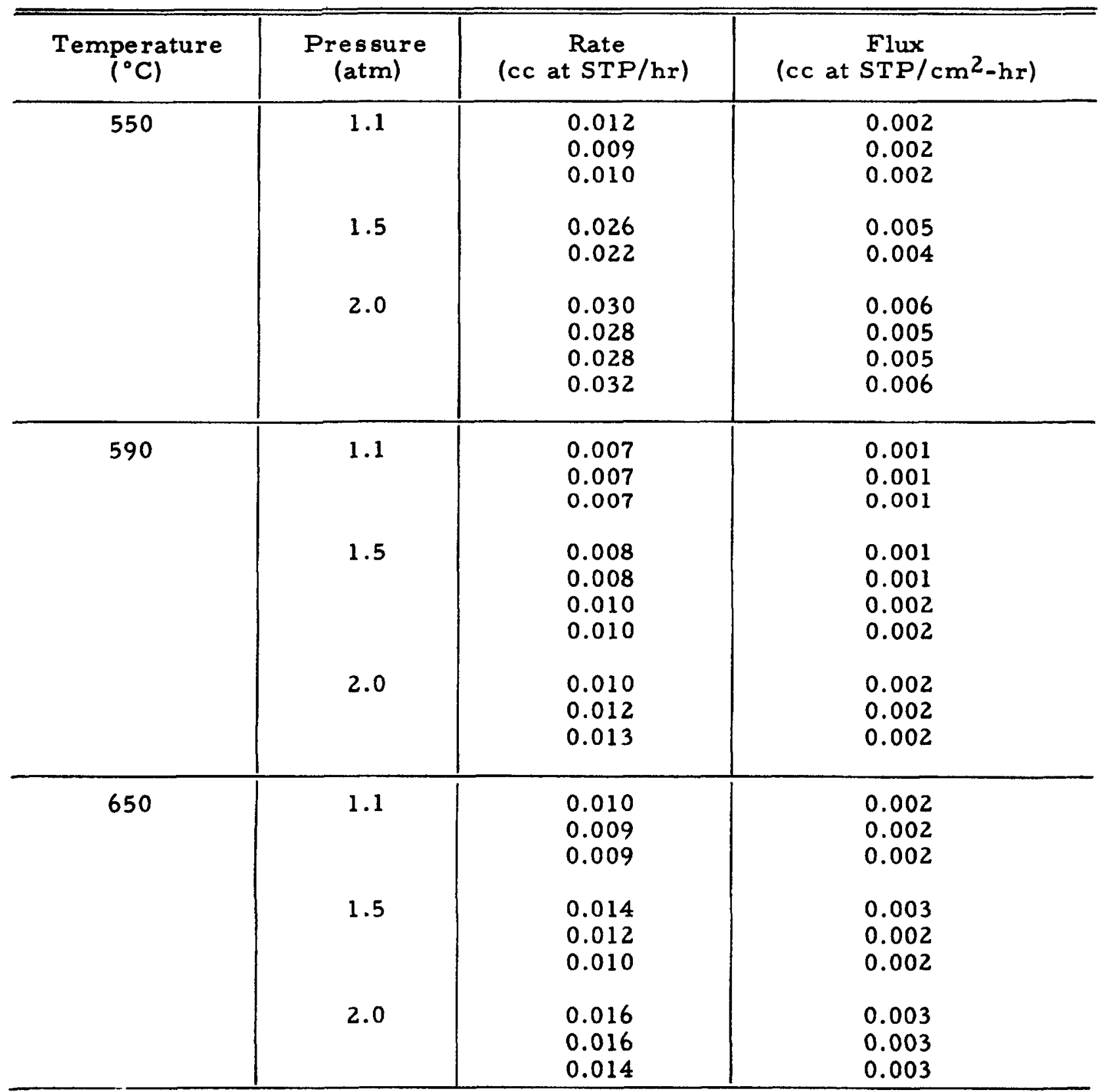


TABLE IX

SUMMARY OF DATA FOR RATE OF HYDROGEN PERMEATION THROUGH CALORIZED AISI-TYPE 430 STAINLESS STEEL MEMBRANE NO. 2

\begin{tabular}{c|c|c|c}
\hline $\begin{array}{c}\text { Temperature } \\
\left({ }^{\circ} \mathrm{C}\right)\end{array}$ & $\begin{array}{c}\text { Pressure } \\
(\text { atm })\end{array}$ & $\begin{array}{c}\text { Rate } \\
\text { (cc at STP/hr) }\end{array}$ & (cc at STP/cm $2-\mathrm{hr}$ ) \\
\hline 550 & 1.1 & 0.010 & 0.002 \\
& 1.5 & 0.024 & 0.004 \\
& 2.0 & 0.029 & 0.005 \\
\hline 590 & 1.1 & 0.007 & 0.001 \\
& 1.5 & 0.009 & 0.002 \\
& 2.0 & 0.011 & 0.002 \\
\hline 650 & 1.1 & 0.009 & 0.002 \\
& 1.5 & 0.012 & 0.002 \\
& 2.0 & 0.015 & 0.003 \\
\hline
\end{tabular}

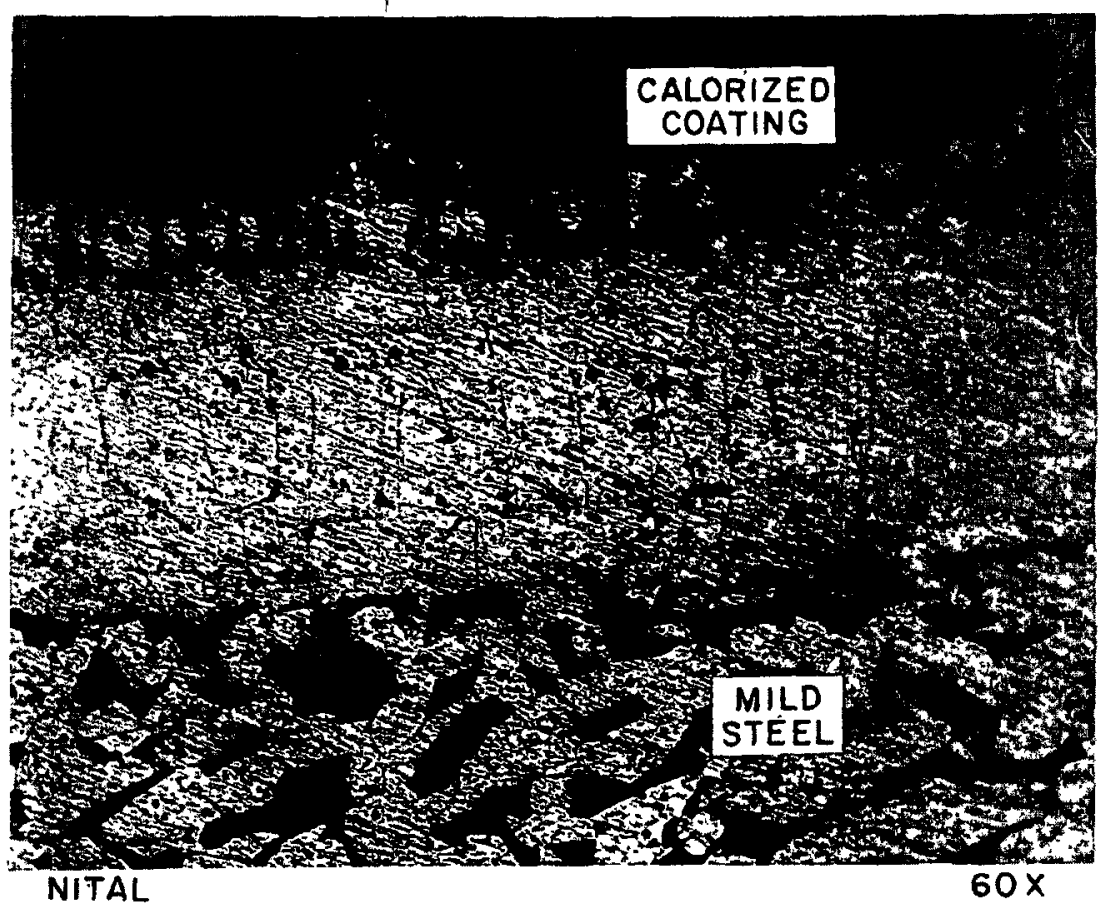

Figure 8. Calorized Mild Steel Specimen 
TABLE X

RATE OF HYDROGEN PERMEATION THROUGH CALORIZED

AISI-TYPE 430 STAINLESS STEEL MEMBRANE NO. 3

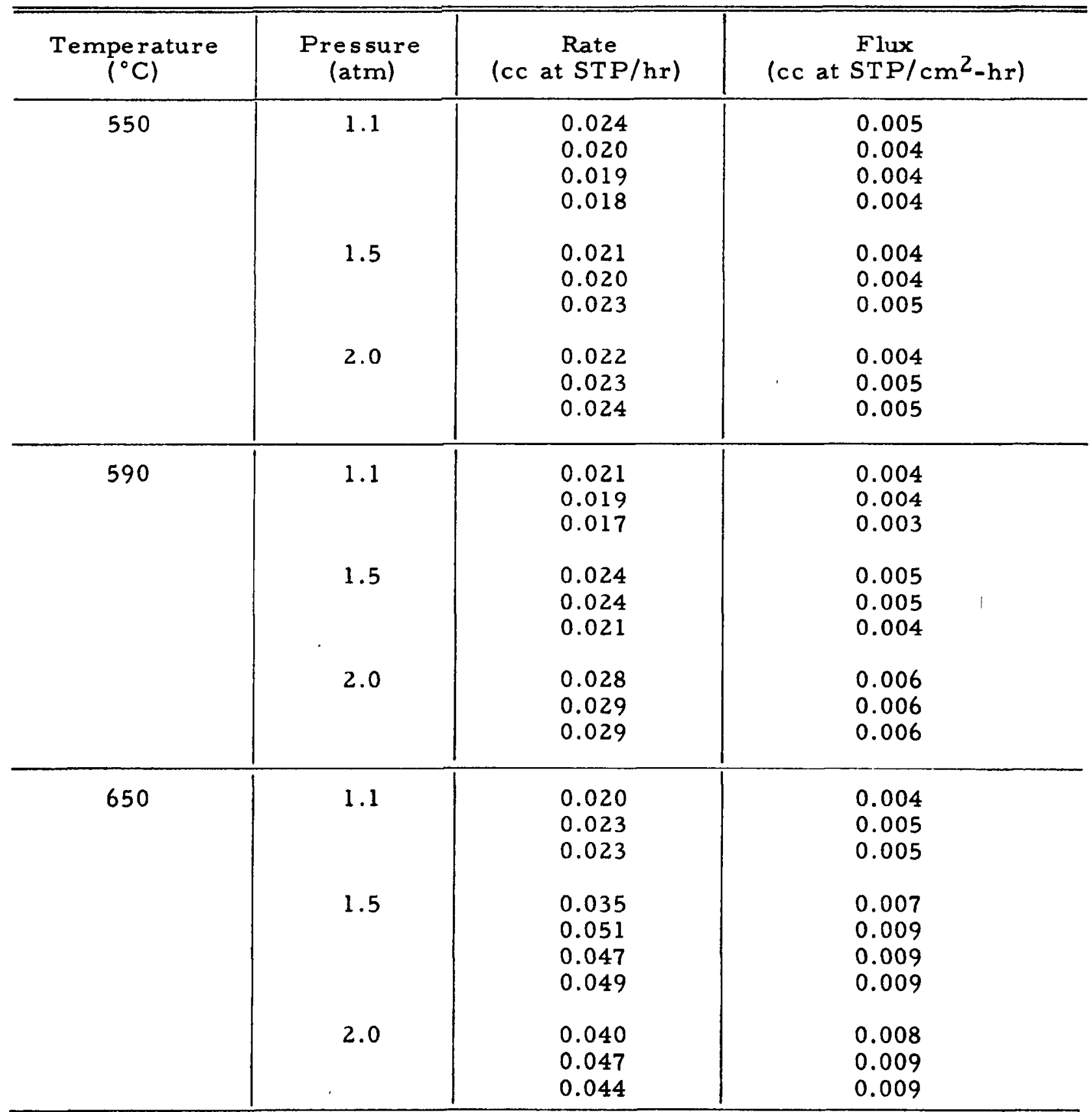


TABLE XI

SUMMARY OF DATA FOR RATE OF HYDROGEN PERMEATION THROUGH CALORIZED AISI-TYPE 430 STAINLESS STEEL MEMBRANE NO. 3

\begin{tabular}{c|c|c|c}
\hline $\begin{array}{c}\text { Temperature } \\
\left({ }^{\circ} \mathrm{C}\right)\end{array}$ & $\begin{array}{c}\text { Pressure } \\
\text { (atm) }\end{array}$ & $\begin{array}{c}\text { Rate } \\
\text { (cc at STP/hr) }\end{array}$ & (cc at STP/cm ${ }^{2}-\mathrm{hr}$ ) \\
\hline 550 & 1.1 & 0.021 & 0.004 \\
& 1.5 & 0.021 & 0.004 \\
& 2.0 & 0.023 & 0.005 \\
\hline \multirow{3}{*}{590} & 1.1 & & \\
& 1.5 & 0.019 & 0.004 \\
& 2.0 & 0.023 & 0.005 \\
& & 0.028 & 0.006 \\
\hline \multirow{3}{*}{650} & 1.1 & & \\
& 1.5 & 0.022 & 0.004 \\
& 2.0 & 0.045 & 0.009 \\
& & 0.044 & 0.009 \\
\hline
\end{tabular}

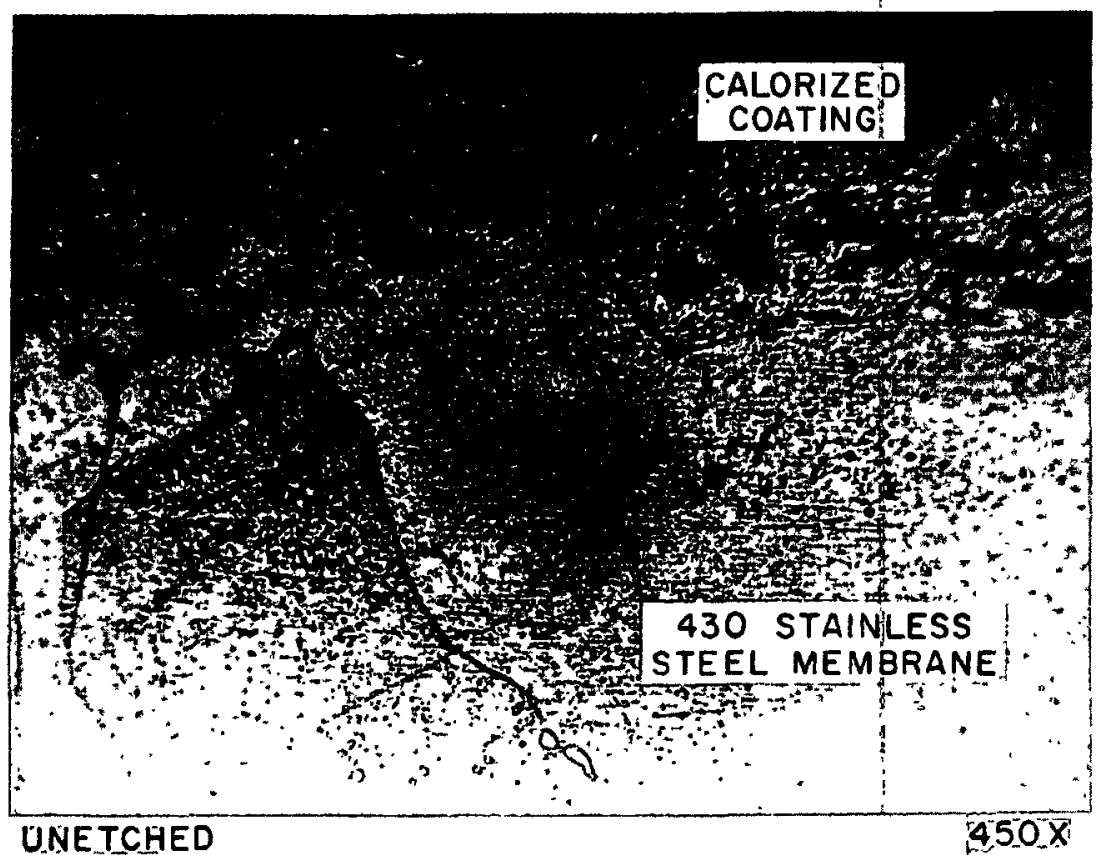

Figure 9. Membrane No. 1 after Permeation Testing 


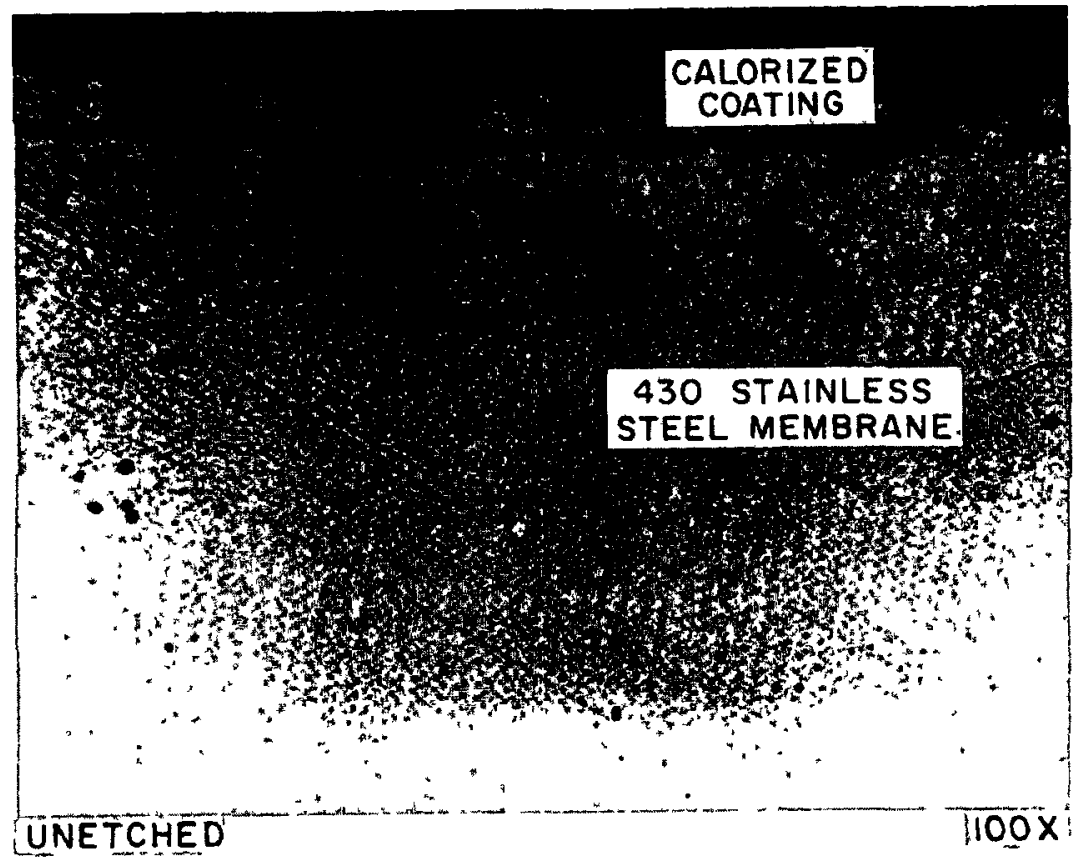

Figure 10. Membrane No. 2 after Permeation Testing 


\section{RATE OF HYDROGEN PERMEATION THROUGH SOLAR-COATED HASTELLOY B}

\section{A. MATERIAL}

The Hastelloy used in this study was the same material as previously reported. 21 The membranes were coated with a proprietary coating sold and applied by Solar Aircraft, San Diego, California. It was agreed to keep the composition of this coating unspecified. A total of three samples was investigated (one membrane being recoated and studied again). The first sample was inverted and its permeability character investigated in this position. The membranes studied were then

\begin{tabular}{clc} 
Membrane & $\begin{array}{c}\text { Metal Dimensions } \\
\text { (in.) }\end{array}$ & $\begin{array}{c}\text { Coating } \\
\text { Thickness } \\
\text { (in.) }\end{array}$ \\
\hline 1 & $\begin{array}{l}\text { Thickness }=0.0656 \\
\text { Diameter }=1.003\end{array}$ & 0.0059 \\
2 & $\begin{array}{l}\text { Thickness }=0.1280 \\
\text { Diameter }=1.003\end{array}$ & 0.005 \\
3 & $\begin{array}{l}\text { Thicknes }=0.0965 \\
\text { Diameter }=1.000\end{array}$ & 0.006
\end{tabular}

\section{B. ACCURACY OF MEASUREMENTS}

The membranes were outgassed at $900^{\circ} \mathrm{C}$. This took approximately one week. After outgassing, blank runs were initiated for $72 \mathrm{hr}$ each at $820^{\circ} \mathrm{C}$. The results of the blank runs are as follow s:

$\begin{array}{cc}\begin{array}{c}\text { Sample } \\ \text { No. }\end{array} & \begin{array}{c}\text { Background } \\ \text { (cc at STP/cm }-\mathrm{hr} \text { ) }\end{array} \\ 1 & 0.00004 \\ 2 & 0.00004 \\ 3 & 0.00004\end{array}$

All three membranes were subjected to a saline solution conductivity test, with the result that 1 and 2 passed the test, but 3 did not. At the conclusion of the investigation, all membranes were again tested in the same manner, and all failed the test. 
TABLE XII

RATE OF HYDROGEN PERMEATION THROUGH HASTELLOY B + SOLARCOATED MEMBRANE NO. 1

\begin{tabular}{|c|c|c|c|}
\hline Temperature & $\begin{array}{l}\text { Pressure } \\
\quad \text { (atm) }\end{array}$ & $\begin{array}{c}\text { Rate } \\
\text { (cc at } S T P / h r)\end{array}$ & $\stackrel{\text { Flux }}{\left(\mathrm{cc} \text { at } \operatorname{STP} / \mathrm{cm}^{2}-\mathrm{hr}\right)}$ \\
\hline 640 & $\begin{array}{l}1.1 \\
1.5 \\
2.0\end{array}$ & $\begin{array}{l}0.032 \\
0.032 \\
0.032 \\
0.038 \\
0.039 \\
0.036 \\
\\
0.046 \\
0.042 \\
0.045\end{array}$ & $\begin{array}{l}0.006 \\
0.006 \\
0.006 \\
\\
0.007 \\
0.007 \\
0.007 \\
\\
0.009 \\
0.008 \\
0.008\end{array}$ \\
\hline $\begin{array}{c}700 \\
- \\
- \\
.\end{array}$ & $\begin{array}{l}1.1 \\
1.5 \\
2.0\end{array}$ & $\begin{array}{l}0.059 \\
0.059 \\
0.059 \\
0.073 \\
0.072 \\
0.072 \\
\\
0.083 \\
0.083 \\
0.084\end{array}$ & $\begin{array}{l}0.012 \\
0.012 \\
0.012 \\
0.014 \\
0.014 \\
0.014 \\
0.016 \\
0.016 \\
0.017\end{array}$ \\
\hline 760 & $\begin{array}{l}1.1 \\
1.5 \\
2.0\end{array}$ & $\begin{array}{l}0.078 \\
0.077 \\
0.078 \\
\\
0.091 \\
0.094 \\
0.089 \\
0.111 \\
0.110 \\
0.110\end{array}$ & $\begin{array}{l}0.015 \\
0.015 \\
0.015 \\
0.018 \\
0.019 \\
0.018 \\
\\
0.022 \\
0.022 \\
0.022\end{array}$ \\
\hline 820 & $\begin{array}{l}1.1 \\
1.5 \\
2.0\end{array}$ & $\begin{array}{l}0.091 \\
0.093 \\
0.092 \\
0.104 \\
0.106 \\
0.105 \\
0.119 \\
0.122 \\
0.121 \\
\end{array}$ & $\begin{array}{l}0.018 \\
0.018 \\
0.018 \\
0.020 \\
0.021 \\
0.021 \\
0.021 \\
0.024 \\
0.023 \\
\end{array}$ \\
\hline
\end{tabular}


The saline solution conductivity test is a measure of the continuity of the coating. One first fills the membrane with a conducting solution. If the coating is completely free of porosity, the resistance of the solution as measured with an ohm meter should be infinite. This procedure has several advantages. First, the readings are easily obtained. It is necessary only to fill the membrane with solution, place one probe in the solution and the other on the membrane metal wall. Second, the solution covers the entire surface of the coating and reveals any defect present.

Nevertheless, it is really a question in the authors' minds whether this test is valid. Of several coated Hastelloy membranes, the one which did not pass this test showed a rate of an order of magnitude lower than two similar membranes which did pass the test. On this basis, and as far as concerns correlating the ability of the coating to create an effective barrier against the flow of hydrogen, the test is somewhat inconclusive. For instance, if the real barrier were not the coating, but the interface of coating and metal, this interface might be conductive to an electrolyte, so that a pinhole which extended to this surface while imparting conductivity to the solution would still be effective as a hydrogen barrier. Another disadvantage of this test is that it does not determine the location of the defect; in determines only if one exists. This disadvantage can be partially overcome by filling the membrane with small successive increments of solution, say one $m \ell$ at a time: this will at least isolate the defect to a smaller area.

\section{DATA}

The data are summarized in Tables XII through XIX. It is seen that membranes 1 and 2 agree, while membrane 3 shows a rate lower than 1 or 2 by an order of magnitude. The wide variation in the data serve to illustrate again, as in the case of the calorized coatings, that coated membranes change in composition and structure with time. This aging effect apparently has a pronounced effect on the permeability characteristics of the coating.

Tables XIV and XV show the data for membrane 1 in the inverted position. It is seen that the rate is reduced over the upright configuration by about $34 \%$ in the low temperature regions; but that at $820^{\circ}$ the rate is about $10 \%$ higher in the inverted position at the higher pressures. There are perhaps two reasons why the behavior of the membrane should be different by inversion. First, 
there is no reason to believe that the properties of the glass are the same in either direction. Second, the particles which first encounter the glass are activated hydrogen atoms, since they have diffused through the metal first. This could be expected to have some effect on the permeability of the glass, since the nature of the diffusing particle might be different.

TABLE XIII

SUMMARY OF DATA FOR RATE OF HYDROGEN PERMEATION THROUGH HASTELLOY B + SOLAR-COATED MEMBRANE NO. 1

\begin{tabular}{c|c|c|c}
\hline $\begin{array}{c}\text { Temperature } \\
\left({ }^{\circ} \mathrm{C}\right)\end{array}$ & $\begin{array}{c}\text { Pressure } \\
\text { (atm) }\end{array}$ & $\begin{array}{c}\text { Rate } \\
\text { (cc at STP/hr) }\end{array}$ & $\begin{array}{c}\text { Flux } \\
\text { (cc at STP/ } \mathrm{cm}^{2} \text {-hr) }\end{array}$ \\
\hline 640 & 1.1 & 0.032 & 0.006 \\
& 1.5 & 0.038 & 0.007 \\
& 2.0 & 0.044 & 0.008 \\
\hline 700 & 1.1 & 0.059 & 0.011 \\
& 1.5 & 0.072 & 0.014 \\
& 2.0 & 0.083 & 0.016 \\
\hline 760 & 1.1 & 0.078 & 0.015 \\
& 1.5 & 0.091 & 0.017 \\
& 2.0 & 0.110 & 0.021 \\
\hline 820 & 1.1 & 0.092 & 0.018 \\
& 1.5 & 0.105 & 0.020 \\
& 2.0 & 0.120 & 0.023 \\
\hline
\end{tabular}

The resistance to flow of a gas through a compound membrane can be treated similarly to an electrical circuit problem, where the total resistance of a series circuit is equal to the sum of the individual resistances. Bearing in mind that conductance is the reciprocal of resistance, we have:

$$
\frac{1}{R_{H}+C}=\frac{1}{R_{H}}+\frac{1}{R_{C}}
$$

where

$$
\begin{aligned}
R_{H+C} & =\text { rate of permeation of Hastelloy }+ \text { coating }(c c \text { at } S T P / h r)^{-1}, \\
R_{H} & =\text { rate of permeation of Hastelloy }(c c \text { at } S T P / h r)^{-1} \text {, and } \\
R_{C} & =\text { rate of permeation of coating }(c c \text { at } S T P / h r)^{-1} .
\end{aligned}
$$$$
\text { NAA-SR- } 6109
$$ 
TABLE XIV

RATE OF HYDROGEN PERMEATION THROUGH HASTELLOY B + CERAMIC COATING MEMBRANE NO. 1, INVERTED

\begin{tabular}{|c|c|c|c|}
\hline $\begin{array}{l}\text { Temperature } \\
\left({ }^{\circ} \mathrm{C}\right)\end{array}$ & $\begin{array}{l}\text { Pressure } \\
\quad(\mathrm{atm})\end{array}$ & $\begin{array}{c}\text { Rate } \\
\text { (cc at STP/hr) }\end{array}$ & $\begin{array}{c}\text { Flux } \\
\left(\mathrm{cc} \text { at } \operatorname{STP} / \mathrm{cm}^{2}-\mathrm{hr}\right)\end{array}$ \\
\hline 640 & $\begin{array}{l}1.1 \\
1.5 \\
2.0\end{array}$ & $\begin{array}{l}0.018 \\
0.024 \\
0.020 \\
0.024 \\
\\
0.028 \\
0.025 \\
0.027 \\
\\
0.030 \\
0.031 \\
0.028\end{array}$ & $\begin{array}{l}0.004 \\
0.005 \\
0.004 \\
0.005 \\
\\
0.006 \\
0.005 \\
0.005 \\
\\
0.006 \\
0.006 \\
0.006\end{array}$ \\
\hline 700 & $\begin{array}{l}1.1 \\
1.5 \\
2.0\end{array}$ & $\begin{array}{l}0.040 \\
0.037 \\
0.035 \\
\\
0.044 \\
0.044 \\
0.044 \\
\\
0.050 \\
0.048 \\
0.049\end{array}$ & $\begin{array}{l}0.008 \\
0.007 \\
0.007 \\
\\
0.009 \\
0.009 \\
0.009 \\
\\
0.010 \\
0.009 \\
0.010\end{array}$ \\
\hline 760 & $\begin{array}{l}1.1 \\
1.5 \\
2.0\end{array}$ & $\begin{array}{l}0.059 \\
0.058 \\
0.057 \\
\\
0.067 \\
0.067 \\
0.070 \\
0.066 \\
\\
0.068 \\
0.065 \\
0.067\end{array}$ & $\begin{array}{l}0.012 \\
0.011 \\
0.011 \\
\\
0.013 \\
0.013 \\
0.014 \\
0.013 \\
\\
0.013 \\
0.013 \\
0.013\end{array}$ \\
\hline 820 & $\begin{array}{l}1.1 \\
1.5 \\
2.0\end{array}$ & $\begin{array}{l}0.088 \\
0.092 \\
0.101 \\
\\
0.119 \\
0.106 \\
0.110 \\
0.017 \\
\\
0.133 \\
0.134 \\
0.136 \\
\end{array}$ & $\begin{array}{l}0.017 \\
0.018 \\
0.020 \\
\\
0.023 \\
0.020 \\
0.021 \\
0.023 \\
\\
0.026 \\
0.026 \\
0.027 \\
\end{array}$ \\
\hline
\end{tabular}


TABLE XV

SUMMARY OF DATA FOR RATE OF HYDROGEN PERMEATION THROUGH HASTELLOY B + CERAMIC COATING MEMBRANE NO. 1, INVERTED

\begin{tabular}{c|c|c|c}
\hline $\begin{array}{c}\text { Temperature } \\
\left({ }^{\circ} \mathrm{C}\right)\end{array}$ & $\begin{array}{c}\text { Pressure } \\
\text { (atm) }\end{array}$ & $\begin{array}{c}\text { Rate } \\
\text { (cc at STP/hr) }\end{array}$ & $\begin{array}{c}\text { Flux } \\
\text { (cc at STP/cm } \text { (chr) }^{2}\end{array}$ \\
\hline \multirow{2}{*}{640} & 1.1 & 0.021 & 0.004 \\
& 1.5 & 0.026 & 0.005 \\
& 2.0 & 0.029 & 0.005 \\
\hline \multirow{2}{*}{700} & 1.1 & 0.037 & 0.007 \\
& 1.5 & 0.044 & 0.008 \\
& 2.0 & 0.049 & 0.009 \\
& 1.1 & 0.058 & 0.011 \\
& 1.5 & 0.068 & 0.013 \\
& 2.0 & 0.066 & 0.013 \\
\hline \multirow{2}{*}{860} & 1.1 & 0.094 & 0.018 \\
& 1.5 & 0.113 & 0.022 \\
& 2.0 & 0.134 & 0.026 \\
\hline
\end{tabular}

If $R_{H} \gg R_{C}$, then $R_{H+C} \cong R_{C}$. In other words, the measured permeability of the duplex membrane is approximately the permeability of the coating alone. The value of $R_{C}$ for Solar-coated membrane No. 1 was calculated using Equation 4 , and the results are found in Table $X X$. The values for $R_{H}$ were calculated from the data on uncoated Hastelloy $B$ found in Reference 21 . It can be seen from this table that the rate of permeation through the Hastelloy $B$ plus coating is about $95 \%$ of the calculated rate through the coating itself. The coating is, therefore, rate-controlling. 
TABLE XVI

RATE OF HYDROGEN PERMEATION THROUGH SOLAR-COATED

HASTELLOY B MEMBRANE NO. 2

\begin{tabular}{|c|c|c|c|}
\hline $\begin{array}{c}\text { Temperature } \\
\left({ }^{\circ} \mathrm{C}\right)\end{array}$ & $\begin{array}{l}\text { Pressure } \\
\text { (atm) }\end{array}$ & $\begin{array}{c}\text { Rate } \\
\text { (cc at STP/hr) }\end{array}$ & $\begin{array}{c}\text { Flux } \\
\left.\text { (cc at } \mathrm{STP} / \mathrm{cm}^{2}-\mathrm{hr}\right)\end{array}$ \\
\hline \multirow[t]{3}{*}{640} & 1.1 & $\begin{array}{l}0.027 \\
0.025 \\
0.025 \\
0.026\end{array}$ & $\begin{array}{l}0.005 \\
0.005 \\
0.005 \\
0.005\end{array}$ \\
\hline & 1.5 & $\begin{array}{l}0.031 \\
0.034 \\
0.030 \\
0.030\end{array}$ & $\begin{array}{l}0.006 \\
0.006 \\
0.006 \\
0.006\end{array}$ \\
\hline & 2.0 & $\begin{array}{l}0.035 \\
0.038 \\
0.043 \\
0.032 \\
0.032\end{array}$ & $\begin{array}{l}0.007 \\
0.008 \\
0.008 \\
0.006 \\
0.006\end{array}$ \\
\hline \multirow[t]{3}{*}{700} & 1.1 & $\begin{array}{l}0.058 \\
0.055 \\
0.054\end{array}$ & $\begin{array}{l}0.011 \\
0.011 \\
0.011\end{array}$ \\
\hline & 1.5 & $\begin{array}{l}0.069 \\
0.066 \\
0.064\end{array}$ & $\begin{array}{l}0.014 \\
0.013 \\
0.013\end{array}$ \\
\hline & 2.0 & $\begin{array}{l}0.065 \\
0.065 \\
0.061 \\
0.061\end{array}$ & $\begin{array}{l}0.013 \\
0.013 \\
0.012 \\
0.013\end{array}$ \\
\hline \multirow[t]{3}{*}{760} & 1.1 & $\begin{array}{l}0.077 \\
0.076 \\
0.072\end{array}$ & $\begin{array}{l}0.015 \\
0.015 \\
0.014\end{array}$ \\
\hline & 1.5 & $\begin{array}{l}0.087 \\
0.085 \\
0.084 \\
0.086\end{array}$ & $\begin{array}{l}0.017 \\
0.017 \\
0.017 \\
0.017\end{array}$ \\
\hline & 2.0 & $\begin{array}{l}0.090 \\
0.096 \\
0.090 \\
0.094 \\
\end{array}$ & $\begin{array}{l}0.018 \\
0.019 \\
0.018 \\
0.019 \\
\end{array}$ \\
\hline
\end{tabular}

With conditions returned to $640^{\circ}$ and $2.0 \mathrm{~atm}$, 640

2.0

0.029

0.006 
TABLE XVII

SUMMARY OF DATA FOR RATE OF HYDROGEN PERMEATION THROUGH SOLAR-COATED HASTELLOY B MEMBRANE NO. 2

\begin{tabular}{c|c|c|c}
\hline $\begin{array}{c}\text { Temperature } \\
\left({ }^{\circ} \mathrm{C}\right)\end{array}$ & $\begin{array}{c}\text { Pressure } \\
\text { (atm) }\end{array}$ & $\begin{array}{c}\text { Rate } \\
\text { (cc at STP/hr) }\end{array}$ & $\begin{array}{c}\text { Flux } \\
\text { (cc at STP/cm } 2-\mathrm{hr} \text { ) }\end{array}$ \\
\hline \multirow{2}{*}{640} & 1.1 & 0.026 & 0.005 \\
& 1.5 & 0.033 & 0.006 \\
& 2.0 & 0.034 & 0.007 \\
\hline \multirow{2}{*}{700} & 1.1 & 0.056 & 0.010 \\
& 1.5 & 0.067 & 0.012 \\
& 2.0 & 0.063 & 0.012 \\
\hline \multirow{2}{*}{760} & 1.1 & 0.075 & 0.014 \\
& 1.5 & 0.085 & 0.016 \\
& 2.0 & 0.092 & 0.018 \\
\hline
\end{tabular}

TABLE XIX*

SUMMARY OF DATA FOR RATE OF HYDROGEN PERMEATION THROUGH SOLAR-COATED HASTELLOY B MEMBRANE NO. 3

\begin{tabular}{|c|c|c|c|}
\hline $\begin{array}{c}\text { Temperature } \\
\left({ }^{\circ} \mathrm{C}\right)\end{array}$ & $\begin{array}{l}\text { Pressure } \\
\text { (atm) }\end{array}$ & $\begin{array}{c}\text { Rate } \\
\text { (cc at STP/hr) }\end{array}$ & $\stackrel{\text { Flux }}{\left(\mathrm{cc} \text { at } \mathrm{STP} / \mathrm{cm}^{2}-\mathrm{hr}\right)}$ \\
\hline 640 & $\begin{array}{l}1.1 \\
1.5 \\
2.0\end{array}$ & $\begin{array}{l}0.010 \\
0.011 \\
0.015\end{array}$ & $\begin{array}{l}0.002 \\
0.002 \\
0.002\end{array}$ \\
\hline 700 & $\begin{array}{l}1.1 \\
1.5 \\
2.0\end{array}$ & $\begin{array}{l}0.019 \\
0.022 \\
0.026\end{array}$ & $\begin{array}{l}0.003 \\
0.004 \\
0.005\end{array}$ \\
\hline 760 & $\begin{array}{l}1.1 \\
1.5 \\
2.0\end{array}$ & $\begin{array}{l}0.036 \\
0.046 \\
0.052\end{array}$ & $\begin{array}{l}0.007 \\
0.009 \\
0.010\end{array}$ \\
\hline
\end{tabular}

*Table XVIII is on page 37. 
TABLE XVIII

RATE OF HYDROGEN PERMEATION THROUGH SOLAR-COATED HASTELLOY B MEMBRANE NO. 3

\begin{tabular}{|c|c|c|c|}
\hline $\begin{array}{l}\text { Temperature } \\
\left({ }^{\circ} \mathrm{C}\right)\end{array}$ & $\begin{array}{l}\text { Pressure } \\
\text { (atm) }\end{array}$ & $\begin{array}{c}\text { Rate } \\
\text { (cc at STP/hr) }\end{array}$ & $\begin{array}{c}\text { Flux } \\
\text { (cc at } S T P / \mathrm{cm}^{2}-\mathrm{hr} \text { ) }\end{array}$ \\
\hline \multirow[t]{3}{*}{640} & 1.1 & $\begin{array}{l}0.011 \\
0.010 \\
0.010\end{array}$ & $\begin{array}{l}0.022 \\
0.002 \\
0.002\end{array}$ \\
\hline & 1.5 & $\begin{array}{l}0.012 \\
0.011 \\
0.012\end{array}$ & $\begin{array}{l}0.002 \\
0.002 \\
0.002\end{array}$ \\
\hline & 2.0 & $\begin{array}{l}0.014 \\
0.015 \\
0.015\end{array}$ & $\begin{array}{l}0.003 \\
0.003 \\
0.003\end{array}$ \\
\hline \multirow[t]{3}{*}{700} & 1.1 & $\begin{array}{l}0.024 \\
0.018 \\
0.017 \\
0.020 \\
0.017\end{array}$ & $\begin{array}{l}0.005 \\
0.004 \\
0.003 \\
0.004 \\
0.004\end{array}$ \\
\hline & 1.5 & $\begin{array}{l}0.021 \\
0.024 \\
0.022 \\
0.022\end{array}$ & $\begin{array}{l}0.004 \\
0.005 \\
0.004 \\
0.004\end{array}$ \\
\hline & 2.0 & $\begin{array}{l}0.027 \\
0.026 \\
0.025\end{array}$ & $\begin{array}{l}0.005 \\
0.005 \\
0.005\end{array}$ \\
\hline \multirow[t]{3}{*}{760} & 1.1 & $\begin{array}{l}0.040 \\
0.036 \\
0.035 \\
0.032\end{array}$ & $\begin{array}{l}0.008 \\
0.007 \\
0.007 \\
0.006\end{array}$ \\
\hline & 1.5 & $\begin{array}{l}0.047 \\
0.048 \\
0.046 \\
0.044\end{array}$ & $\begin{array}{l}0.009 \\
0.010 \\
0.009 \\
0.009\end{array}$ \\
\hline & 2.0 & $\begin{array}{l}0.052 \\
0.052 \\
0.052\end{array}$ & $\begin{array}{l}0.010 \\
0.010 \\
0.010\end{array}$ \\
\hline
\end{tabular}


TABLE XX

CALCULATED PERMEATION RATE OF SOLAR COATING ( $\left.\mathrm{R}_{\mathrm{C}}\right)$

\begin{tabular}{|c|c|c|c|c|c|c|}
\hline $\begin{array}{c}\text { Temperature } \\
\left({ }^{\circ} \mathrm{C}\right)\end{array}$ & $\begin{array}{c}P \\
(\mathrm{~atm})\end{array}$ & $\begin{array}{c}1 / R_{H}+C \\
(\text { cc at STP/hr })^{-1}\end{array}$ & $\begin{array}{c}1 / R_{H} \\
\text { (cc at } \mathrm{STP} / \mathrm{hr})^{-1}\end{array}$ & $\begin{array}{c}1 / R C \\
(\mathrm{cc} \text { at } \mathrm{STP} / \mathrm{hr})^{-1}\end{array}$ & $\begin{array}{c}R_{C} \\
\text { (cc at } S T P / h r)\end{array}$ & $c=\frac{\mathrm{R}_{\mathrm{H}}+\mathrm{C}}{(\mathrm{cc} \text { at } \mathrm{STP} / \mathrm{hr} \text { ) }}$ \\
\hline 760 & $\begin{array}{l}1.1 \\
1.5 \\
2.0\end{array}$ & $\begin{array}{r}12.89 \\
10.98 \\
9.09\end{array}$ & $\begin{array}{l}0.596 \\
0.510 \\
0.442\end{array}$ & $\begin{array}{r}12.29 \\
10.47 \\
8.65\end{array}$ & $\begin{array}{l}0.0814 \\
0.0955 \\
0.136\end{array}$ & $\begin{array}{l}0.0776 \\
0.0911 \\
0.110\end{array}$ \\
\hline 700 & $\begin{array}{l}1.1 \\
1.5 \\
2.0\end{array}$ & $\begin{array}{l}16.78 \\
13.81 \\
11.99\end{array}$ & $\begin{array}{l}0.985 \\
0.847 \\
0.728\end{array}$ & $\begin{array}{l}15.79 \\
12.96 \\
11.26\end{array}$ & $\begin{array}{l}0.0633 \\
0.0772 \\
0.0887\end{array}$ & $\begin{array}{l}0.0596 \\
0.0724 \\
0.0834\end{array}$ \\
\hline 640 & $\begin{array}{l}1.1 \\
1.5 \\
2.0\end{array}$ & $\begin{array}{l}31.25 \\
26.53 \\
22.73\end{array}$ & $\begin{array}{l}1.731 \\
1.493 \\
1.293\end{array}$ & $\begin{array}{l}30.52 \\
25.03 \\
21.44\end{array}$ & $\begin{array}{l}0.0328 \\
0.0400 \\
0.0467\end{array}$ & $\begin{array}{l}0.0320 \\
0.0377 \\
0.0440\end{array}$ \\
\hline
\end{tabular}




\section{RATEOF HYDROGEN PERMEATION THROUGH J-2 AND J-8 GLASSES}

\section{A. MATERIAL}

The glass coatings, designated J-2 and J-8, were obtained at the Department of Ceramic Engineering, University of Illinois. They were supplied by Dr. Lauchner as milled slip, and were sprayed on the preoxidized $\left(600^{\circ} \mathrm{F}\right.$ in air) 304 stainless steel membranes. They were subsequently fired at $1800^{\circ} \mathrm{F}$. Two coats of the enamel were used, giving a total coating thickness of about 0.003 in. for $\mathrm{J}-2$ and 0.007 in. for J-8. The frit compositions are given below. The principal difference in the formulations is that J-8 is boron-free.

\begin{tabular}{|c|c|c|c|}
\hline Compound & $\begin{array}{c}J-2 \\
\text { (wt \%) } \\
\end{array}$ & Compound & $\begin{array}{c}\mathrm{J}-8 \\
\text { (wt \%) } \\
\end{array}$ \\
\hline $\mathrm{SiO}_{2}$ & 46.4 & $\mathrm{SiO}_{2}$ & 49.4 \\
\hline $\mathrm{Na}_{2} \mathrm{O}$ & 2.7 & $\mathrm{Na}_{2} \mathrm{O}$ & 2.8 \\
\hline $\mathrm{K}_{2} \mathrm{O}$ & 1.3 & $\mathrm{~K}_{2} \mathrm{O}$ & 1.4 \\
\hline $\mathrm{BaO}$ & 17.8 & $\mathrm{BaO}$ & 18.7 \\
\hline $\mathrm{TiO}_{2}$ & 9.4 & $\mathrm{TiO}_{2}$ & 9.8 \\
\hline $\mathrm{ZnO}$ & 3.8 & $\mathrm{MgO}$ & 0.8 \\
\hline $\mathrm{CaO}$ & 2.1 & $\mathrm{SrO}_{2}$ & 1.0 \\
\hline $\mathrm{MgO}$ & 0.5 & $\mathrm{CaO}$ & -- \\
\hline $\mathrm{B}_{2} \mathrm{O}_{3}$ & 8.0 & $\mathrm{ZrO}_{2}$ & 7.0 \\
\hline $\mathrm{Li}_{2} \mathrm{O}$ & 0.8 & $\mathrm{SiO}_{2}$ & $\cdots$ \\
\hline \multirow{4}{*}{$\mathrm{ZrO}_{2}$} & 7.2 & $\mathrm{ZnO}$ & 4.3 \\
\hline & & $\mathrm{ZrO}_{2}$ & 1.4 \\
\hline & & $\mathrm{CeO}$ & 2.8 \\
\hline & & $\mathrm{Li}_{2} \mathrm{O}$ & 0.8 \\
\hline
\end{tabular}

Prior to investigation, the J-2-1 and J-2-2 coated membranes all passed the conductivity test, indicating good continuity of the coatings. At the conclusion of the investigation, however, the coatings failed this test, indicating that they had developed a certain porosity. The coating parted from one membrane $(\mathrm{J}-2-1)$ in two small spots as a result of the testing. The spalled areas are shown in Figure 11. In spite of the appearance of J-2-1, substantial agreement was obtained. From this, we conclude that either the parting of the glass from 


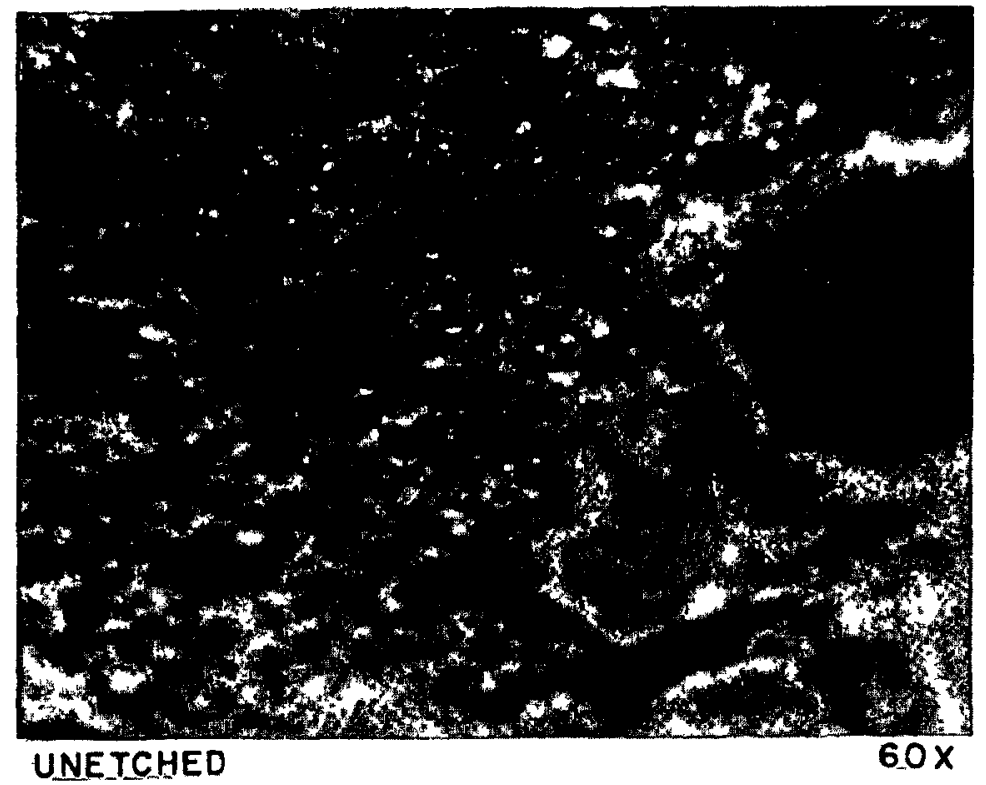

Figure 11. Surface of J-2-1 Coating

the metal took place after the investigation, or that when it did part, it left enough glass behind to inhibit the passage of hydrogen through the metal, or that after parting, an oxide film of similar permeability character remained.

The coating-membrane interface and the amorphous structure of the coating are illustrated in Figure 12.

The J-8 coated membrane became considerably changed in structure and appearance, as is evident in the photomicrographs in Figures 13 and 14. After investigation, the coating was black, and had lost its gloss. The surface was populated by metallic appearing specks. Finally, a large quantity of precipitate was noted throughout the coating (Figure 14). This may well be barium silicate crystallized out by the titania acting as a nucleatıng agent.

\section{B. ACCURACY OF MEASUREMENTS}

The membranes coated with J-2 and J-8 coatings were outgassed for $72 \mathrm{hr}$ at $820^{\circ} \mathrm{C}$. The temperatures were then lowered to $760^{\circ} \mathrm{C}$ and blank runs initiated. These blank runs lasted, on an average, 14 days, at which time the background was negligible.

C. DATA

The data for membranes J-2-1, J-2-2, and J-8 are tabulated in Tables XXI through XXIV. From Table XXII the reader can determine the reproducibility 


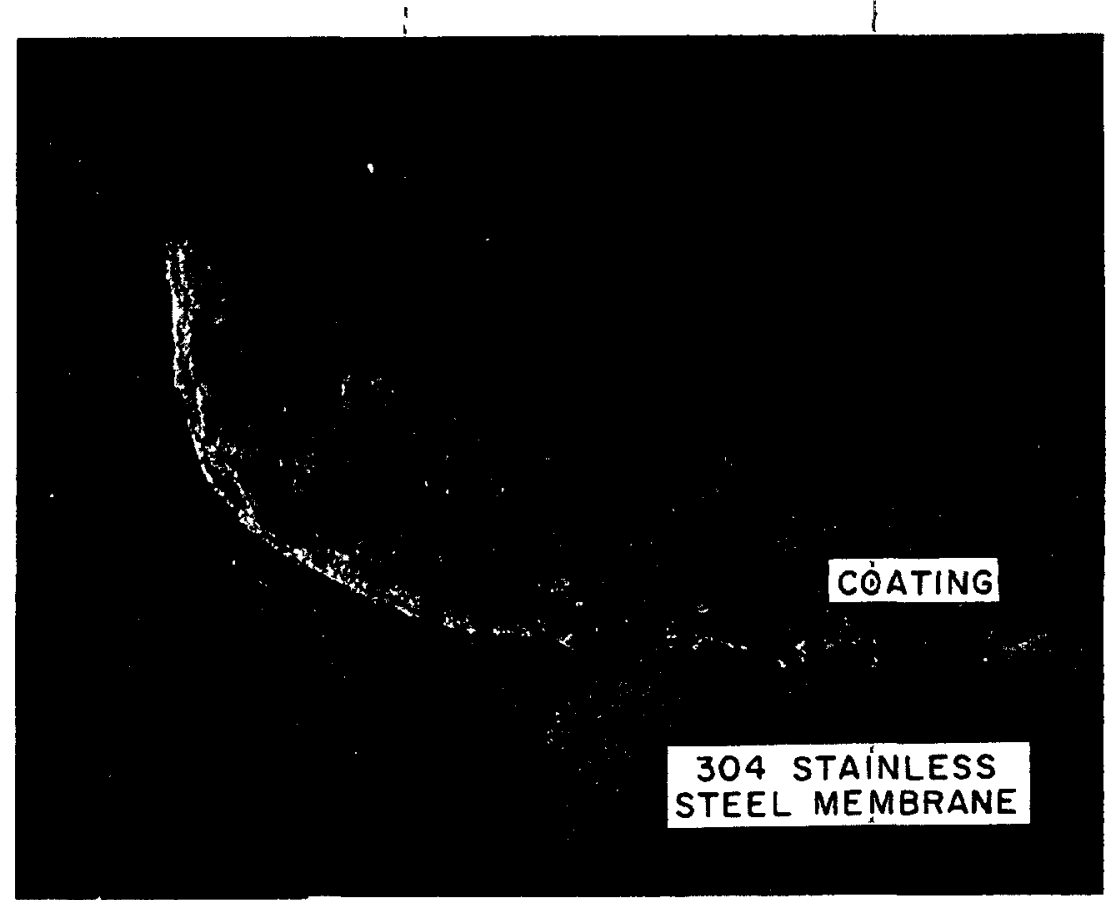

AOUA REGIA

$150 x$

Figure 12. Cross Section of J-2-2

Membrane at Corner Area

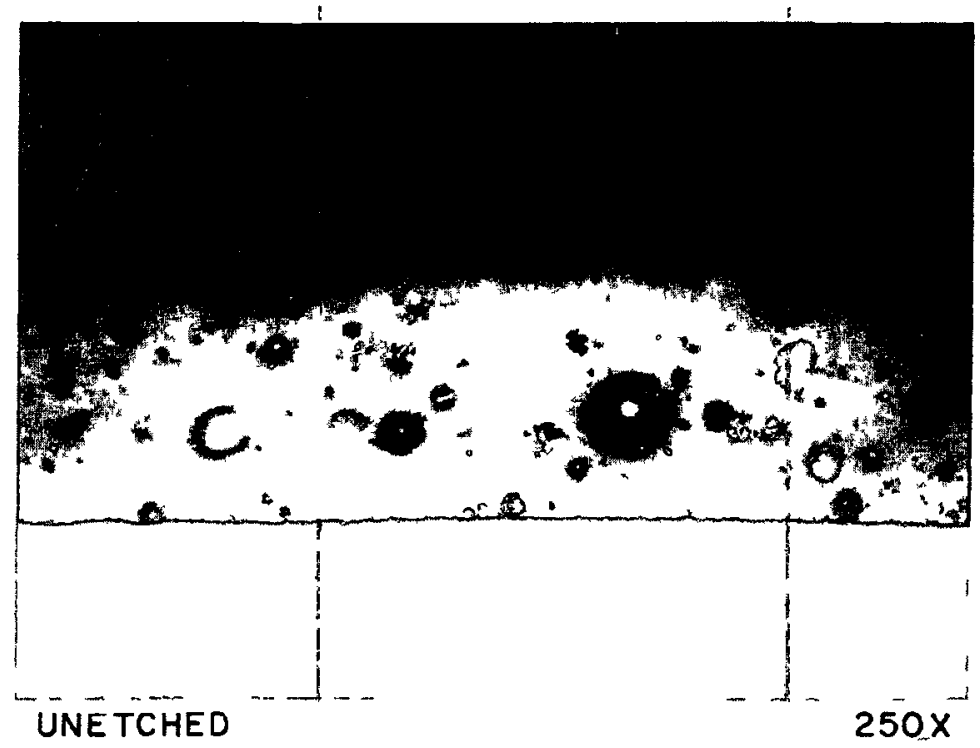

Figure 13. Cross Section of J-8 Coating in the As-fired Condition 


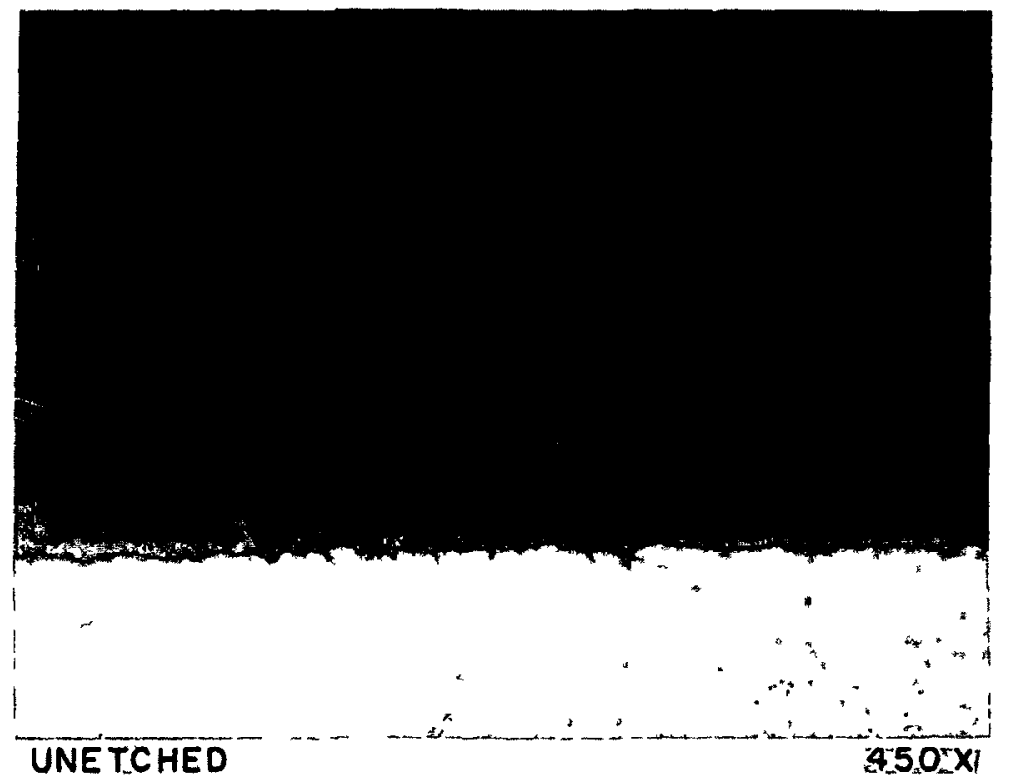

Figure 14. Cross Section of J-8 Coating after Permeation Testing

of the experiment, since here are shown the fluxes originally measured alongside the values measured during later experimentation with the same membrane.

The reproducibility of the coating character is apparent from Table XXIII where the data for the two membranes are summarized together. The average agreement is about $10 \%$, although in one case it is as poor as $27 \%$.

The data for the membrane coated with J-8 glass is given in Table XXIV. At the conclusion of the investigation, several points were rechecked as time permitted. These data, also found in Table XXIV, give an indication of the reproducibility of the measurements. 
TABLE XXI

RATE OF HYDROGEN PERMEATION THROUGH

SAMPLE J-2-1

Coating Thickness $=0.003 \mathrm{in}$.

\begin{tabular}{|c|c|c|}
\hline $\begin{array}{l}\text { Temperature } \\
\left({ }^{\circ} \mathrm{C}\right)\end{array}$ & $\begin{array}{l}\text { Pressure } \\
(\text { atm })\end{array}$ & $\underset{\left.\text { (cc at } \mathrm{STP} / \mathrm{cm}^{2}-\mathrm{hr}\right)}{\stackrel{\text { Flux }}{ }}$ \\
\hline \multirow[t]{3}{*}{640} & 1.1 & $\begin{array}{l}0.0076 \\
0.0073 \\
0.0082 \\
0.0072 \\
0.0071\end{array}$ \\
\hline & 1.5 & $\begin{array}{l}0.0086 \\
0.0082\end{array}$ \\
\hline & 2.0 & $\begin{array}{l}0.0109 \\
0.0112 \\
0.0112 \\
0.0116\end{array}$ \\
\hline \multirow[t]{3}{*}{700} & 1.1 & $\begin{array}{l}0.0118 \\
0.0118 \\
0.0126\end{array}$ \\
\hline & 1.5 & $\begin{array}{l}0.0136 \\
0.0141 \\
0.0132\end{array}$ \\
\hline & 2.0 & $\begin{array}{l}0.0151 \\
0.0201 \\
0.0182 \\
0.0179 \\
0.0170 \\
0.0191 \\
0.0159 \\
0.0208\end{array}$ \\
\hline \multirow[t]{3}{*}{760} & 1.1 & $\begin{array}{l}0.0194 \\
0.0161 \\
0.0136 \\
0.0223 \\
0.0141 \\
0.0223 \\
0.0188 \\
0.0177 \\
0.0174\end{array}$ \\
\hline & 1.5 & $\begin{array}{l}0.0198 \\
0.0233 \\
0.0246 \\
0.0255\end{array}$ \\
\hline & 2.0 & $\begin{array}{l}0.0274 \\
0.0251 \\
0.0268 \\
0.0263 \\
\end{array}$ \\
\hline
\end{tabular}

NAA-SR-6109 
TABLE XXII

RATE OF HYDROGEN PERMEATION THROUGH SAMPLE J-2-2 Coating Thickness $=0.003$ in .

\begin{tabular}{|c|c|c|c|}
\hline \multirow{2}{*}{$\begin{array}{c}\text { Temperature } \\
\left({ }^{\circ} \mathrm{C}\right)\end{array}$} & \multirow{2}{*}{$\begin{array}{l}\text { Pressure } \\
\quad \text { (atm) }\end{array}$} & \multicolumn{2}{|c|}{$\begin{array}{c}\text { Flux } \\
\text { (cc at STP } / \mathrm{cm}^{2}-\mathrm{hr} \text { ) }\end{array}$} \\
\hline & & $\begin{array}{c}\text { Original } \\
\text { Measurements }\end{array}$ & $\begin{array}{l}\text { Rechecked } \\
\text { Values }\end{array}$ \\
\hline \multirow[t]{3}{*}{640} & 1.1 & $\begin{array}{l}0.0081 \\
0.0081 \\
0.0079\end{array}$ & $\begin{array}{l}0.0082 \\
0.0081 \\
0.0079\end{array}$ \\
\hline & 1.5 & $\begin{array}{l}0.0079 \\
0.0079 \\
0.0076\end{array}$ & $\begin{array}{l}0.0088 \\
0.0085 \\
0.0082\end{array}$ \\
\hline & 2.0 & $\begin{array}{l}0.0083 \\
0.0080 \\
0.0083\end{array}$ & $\begin{array}{l}0.0083 \\
0.0078 \\
0.0082\end{array}$ \\
\hline \multirow[t]{3}{*}{700} & 1.1 & $\begin{array}{l}0.0135 \\
0.0136 \\
0.0140 \\
0.0135\end{array}$ & $\begin{array}{l}0.0134 \\
0.0142 \\
0.0139\end{array}$ \\
\hline & 1.5 & $\begin{array}{l}0.0143 \\
0.0145\end{array}$ & $\begin{array}{l}0.0128 \\
0.0131 \\
0.0129\end{array}$ \\
\hline & 2.0 & $\begin{array}{l}0.0170 \\
0.0169 \\
0.0172 \\
0.0165\end{array}$ & \\
\hline \multirow[t]{3}{*}{760} & 1.1 & $\begin{array}{l}0.0187 \\
0.0188 \\
0.0187\end{array}$ & $\begin{array}{l}0.0187 \\
0.0180\end{array}$ \\
\hline & 1.5 & $\begin{array}{l}0.0205 \\
0.0210 \\
0.0205\end{array}$ & $\begin{array}{l}0.0192 \\
0.0184 \\
0.0184 \\
0.0193\end{array}$ \\
\hline & 2.0 & $\begin{array}{l}0.0349 \\
0.0254 \\
0.0252\end{array}$ & \\
\hline
\end{tabular}




\section{RATE OF HYDROGEN PERMEATION THROUGH J-5 GLASS}

A. MATERIAL

The J-5 glass, like the J-2 and J-8 compositions, was supplied in slip form by Dr. Lauchner, of the University of Illinois. It was sprayed on the oxidized 304 stainless steel membrane and fired at $1600^{\circ} \mathrm{F}$. From the frit formulation, shown just below, it is apparent that J-5 is quite a different glass from J-2 or J-8.

\begin{tabular}{lrllc}
\multicolumn{1}{c}{ Compound } & Wt $\%$ & & Compound & $\frac{\text { Wt } \%}{\mathrm{SiO}_{2}}$ \\
\cline { 2 - 4 } & 42.9 & Copper Oxide (black) & 0.6 \\
Dehyd. Borax & 4.9 & CoO & 0.86 \\
Keystone Feldspar & 21.0 & Litharge & 16.3 \\
Soda Nitre & 2.8 & Chromium Oxide & 0.6 \\
$\mathrm{TiO}_{2}$ & 6.4 & $\mathrm{Fe}_{2} \mathrm{O}_{3}$ & 0.2 \\
$\mathrm{MnO}$ & 0.23 & Nickel Oxide (black) & 0.1
\end{tabular}

In place of baria and titania as two major constituents (after silica), we now have keystone feldspar (a complex aluminum silicate) and litharge (PbO).

TABLE XXIII

SUMMARY OF DATA FOR SAMPLES J-2-1 AND J-2-2

\begin{tabular}{c|c|c|c}
\hline \multirow{2}{*}{$\begin{array}{c}\text { Temperature } \\
\left({ }^{\circ} \mathrm{C}\right)\end{array}$} & $\begin{array}{c}\text { Pressure } \\
\text { (atm) }\end{array}$ & \multicolumn{2}{|c}{$\begin{array}{c}\text { Flux } \\
\left.\text { (cc at STP/cm }{ }^{2}-\mathrm{hr}\right)\end{array}$} \\
\cline { 2 - 4 } & 1.1 & $\mathrm{~J}-2-1$ & $\mathrm{~J}-2-2$ \\
\hline \multirow{2}{*}{640} & 1.5 & 0.0075 & 0.0081 \\
& 2.0 & 0.0083 & 0.0085 \\
& 1.1 & 0.0112 & 0.0081 \\
\hline \multirow{2}{*}{700} & 1.5 & 0.0120 & 0.0138 \\
& 2.0 & 0.0136 & 0.0139 \\
& 1.1 & 0.0182 & 0.0169 \\
\hline \multirow{2}{*}{760} & & 0.0180 & 0.0185 \\
& 1.0 & 0.0233 & 0.0198 \\
& & 0.0265 & 0.0285 \\
\hline
\end{tabular}

NAA-SR-6109 
TABLE XXIV

RATE OF HYDROGEN PERMEATION THROUGH SAMPLE J-8 Coating Thickness $=0.007$ in.

\begin{tabular}{|c|c|c|c|}
\hline \multirow{2}{*}{$\begin{array}{c}\text { Temperature } \\
\left({ }^{\circ} \mathrm{C}\right)\end{array}$} & \multirow{2}{*}{$\begin{array}{c}\text { Pressure } \\
\text { (atm) }\end{array}$} & \multicolumn{2}{|c|}{$\begin{array}{c}\text { Flux } \\
\left\langle c c \text { at } \operatorname{STP} / \mathrm{cm}^{2}-\mathrm{hr}\right\rangle\end{array}$} \\
\hline & & $\begin{array}{c}\text { Original } \\
\text { Measurements }\end{array}$ & $\begin{array}{l}\text { Rechecked } \\
\text { Values }\end{array}$ \\
\hline \multirow[t]{3}{*}{640} & 1.1 & $\begin{array}{l}0.0067 \\
0.0066 \\
0.0062 \\
0.0058\end{array}$ & \\
\hline & 1.5 & $\begin{array}{l}0.0076 \\
0.0075 \\
0.0083 \\
0.0069\end{array}$ & $\begin{array}{l}0.0059 \\
0.0063 \\
0.0058\end{array}$ \\
\hline & 2.0 & $\begin{array}{l}0.0065 \\
0.0063 \\
0.0063\end{array}$ & $\begin{array}{l}0.0065 \\
0.0061 \\
0.0063 \\
0.0061\end{array}$ \\
\hline \multirow[t]{3}{*}{700} & 1.1 & $\begin{array}{l}0.0101 \\
0.0090 \\
0.0092 \\
0.0099\end{array}$ & \\
\hline & 1.5 & & $\begin{array}{l}0.0101 \\
0.0102 \\
0.0100\end{array}$ \\
\hline & 2.0 & $\begin{array}{l}0.0109 \\
0.0109 \\
0.0105\end{array}$ & $\begin{array}{l}0.0107 \\
0.0108 \\
0.0106 \\
0.0106\end{array}$ \\
\hline \multirow[t]{3}{*}{760} & 1.1 & $\begin{array}{l}0.0161 \\
0.0145 \\
0.0160 \\
0.0145\end{array}$ & \\
\hline & 1.5 & $\begin{array}{l}0.0230 \\
0.0232 \\
0.0230 \\
0.0227\end{array}$ & \\
\hline & 2.0 & $\begin{array}{l}0.0256 \\
0.0253 \\
0.0250 \\
0.0250 \\
\end{array}$ & \\
\hline
\end{tabular}


The coating-membrane interface after testing is shown in Figure 15. This particular coating, although being extremely impenetrable to hydrogen, was not very adherent. It was, therefore, difficult to section the mounted specimen

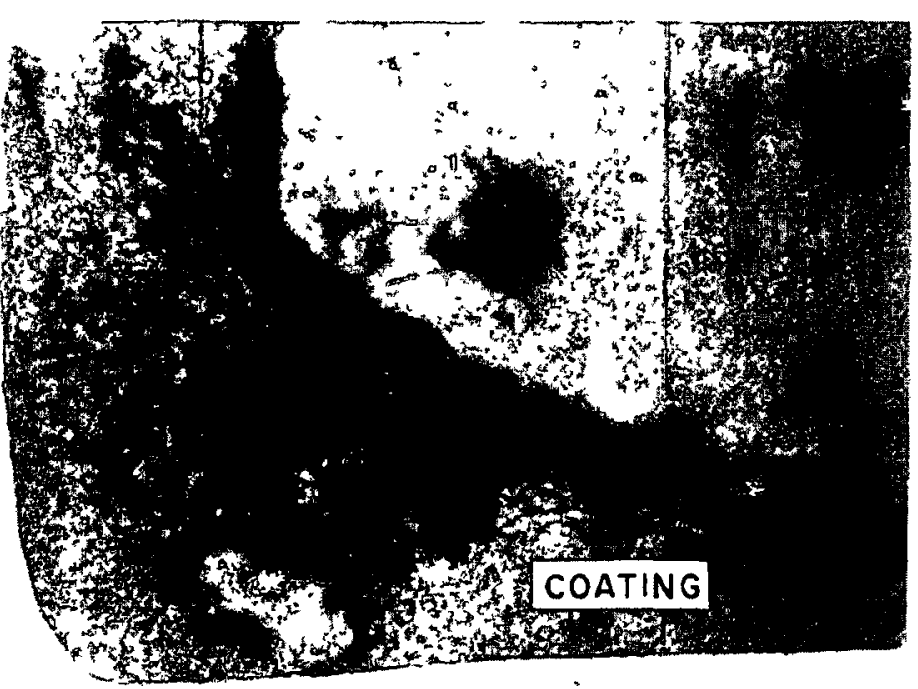

304 STAINLESS

STEEL MEMBRANE

\section{UNETCHED}

$150 \times$

Figure 15. Cross Section of Corner of J-5-Coated Membrane after Testing

without damaging the interface. In view of this, it is difficult to determine if the holes in the coating shown in Figure 15 were caused by the metallographic preparation or were in the glass during study.

\section{B. ACCURACY}

The coated membrane was outgassed for $72 \mathrm{hr}$ at $820^{\circ} \mathrm{C}$. The temperature was then lowered to $760^{\circ} \mathrm{C}$ and the blank run initiated. The blank run lasted about 14 days, after which the background was down to about $0.0006 \mathrm{cc}$ at STP/ $c m^{2}-h r$.

C. DATA

The experimental data for the J-5 coated membrane are given in Table XXV. The J-5 coating is the least permeable coating tested. Unfortunately, the membrane developed a leak in the weld after the testing at $640^{\circ} \mathrm{C}$, and there was insufficient time for repair and resumption of the study at higher temperatures.

$$
\text { NAA-SR-6109 }
$$


TABLE XXV

RATE OF HYDROGEN PERMEATION THROUGH SAMPLE J5

\begin{tabular}{|c|c|c|}
\hline $\begin{array}{c}\text { Temperature } \\
\left({ }^{\circ} \mathrm{C}\right)\end{array}$ & $\begin{array}{l}\text { Pressure } \\
\text { (atm) }\end{array}$ & $\begin{array}{c}\text { Flux } \\
\left.\text { (cc at } \mathrm{STP} / \mathrm{cm}^{2}-\mathrm{hr}\right)\end{array}$ \\
\hline 640 & 1.5 & $\begin{array}{l}0.00073 \\
0.00075 \\
0.00071\end{array}$ \\
\hline 700 & 1.5 & $\begin{array}{l}0.00085 \\
0.00091 \\
0.00084 \\
0.00108 \\
0.00087\end{array}$ \\
\hline 760 & 1.5 & $\begin{array}{l}0.00174 \\
0.00186 \\
0.00189 \\
0.00199\end{array}$ \\
\hline
\end{tabular}




\section{SUMMARY AND CONCLUSIONS}

The experimental data are summarized in Figure 16, which shows a plot of flux (cc at STP $/ \mathrm{cm}^{2}-\mathrm{hr}$ ) of hydrogen through various materials as a function of temperature. All the data in this graph are for a 1.1 atmosphere differential pressure of hydrogen. The most salient feature of the data when displayed in this manner is the extreme impermeability of surface-treated metals as compared to untreated metals. Only 3 to $7 \mathrm{mils}$ of a suitable, high-temperature glass enamel or 10 mils of surface calorizing is 10 to 100 times more effective as a hydrogen barrier than 60 to 120 mils of untreated steel.

Theory predicts that the flux of hydrogen through a metal membrane is inversely proportional to the membrane thickness. When deviations from this behavior are noted in actual experiments, the difficulty can generally be traced to surface oxidation.

Since the thickness dependence of the flux of hydrogen through a glass enamel coating has not been defined precisely, one can not determine whether the controlling step in the process is adsorption on the surface or rate of diffusion of hydrogen through the solid.

When a thin coating reduces the flux through a metal by 1 to 2 orders of magnitude, it is proper to report the flux as being characteristic of the coating without specifying the dimensions and composition of the underlying metal. 


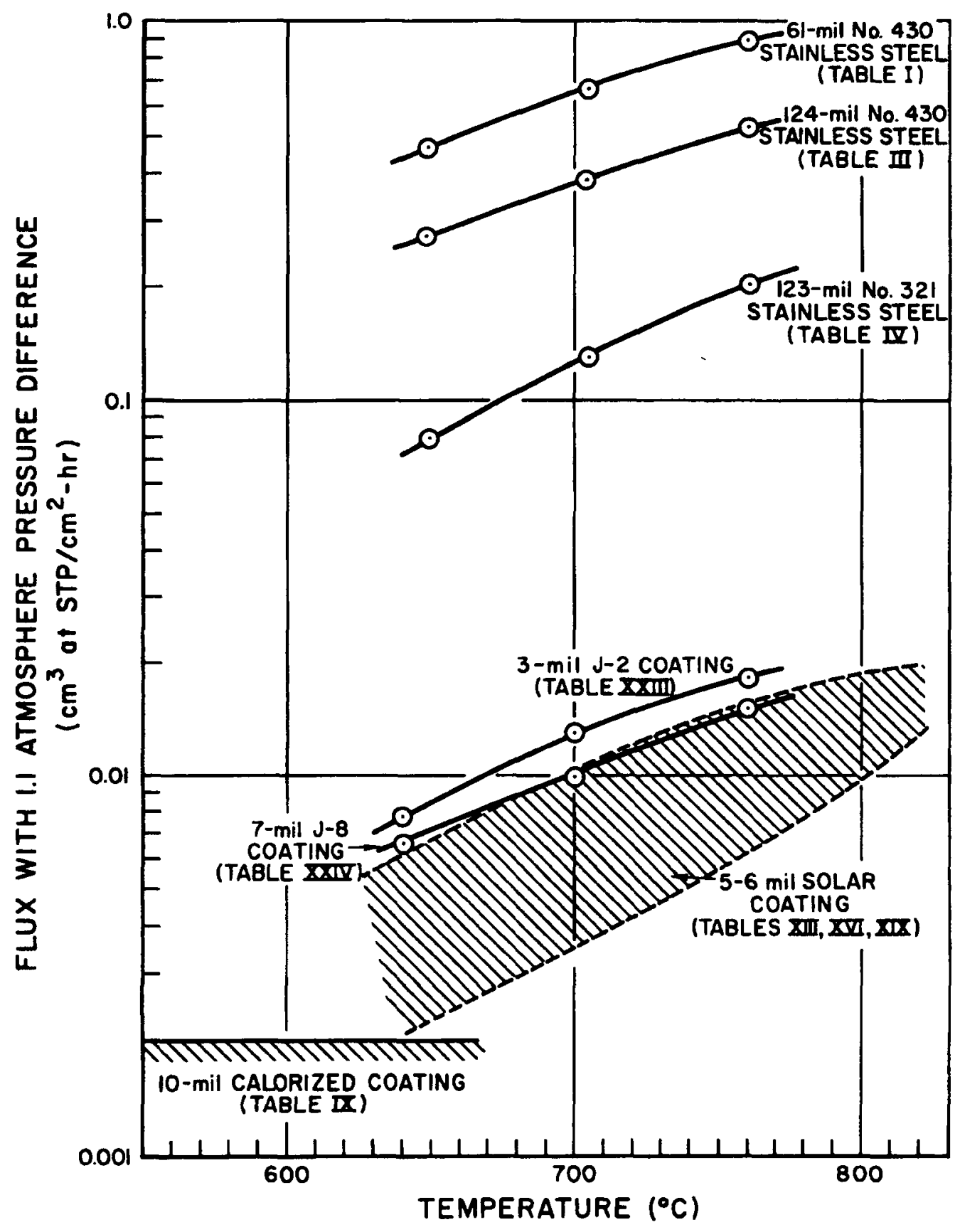

Figure 16. Comparison of Permeabilities of Several Materials at 1.1 Atmosphere of Hydrogen Pressure Differential 


\section{REFERENCES}

1. C. J. Smithells, Gases and Metals, John Wiley and Sons (1937), Ch. II

2. C. J. Smithells and C. E. Ransley, Proc. Roy. Soc. (London 1935), A, $\underline{150}, 172$

3. H. M. Ryder, Elect. F., 17, 161 (1920)

4. W. Baukloh and H. Kayser, Z. Metallik.,26, 156 (1934)

5. F. M. G. Johnson and P. Larose, J. Am. Chem. Soc., 46, 1377 (1924)

6. V. Lombard, C. Rend., 177, 116 (1923)

7. G. Lewkonja and W. Baukloh, Z. Metallik., 25, 309 (1933)

8. S. Johnson, Permeability of Inconel to Hydrogen, private communication

9. W. J. Urry, J. Am. Chem. Soc., 54, 3887 (1932)

10. R. M. Barrer, Diffusion In and Through Solids, The Macmillan Company (1941), Chapter III

11. E. O. Braaten and G. Clark, J. Am. Chem. Soc., 57, 2714 (1935)

12. W. Roeser, Bur. Stand. J. Res., Wash., 7, 485 (1931)

13. W. Baukloh and H. Kayser, Z. Metallik., 27, 281 (1935)

14. P. S. Flint, "Diffusion of Hydrogen Through Materials of Construction," General Electric Co. KAPL-659

15. C. J. Smithells and C. E. Ransley, Proc. Roy. Soc. (London 1935) A, $\underline{152}, 706$

16. F. M. G. Johnson and P. Larose, J. Am. Chem. Soc., 49, 312 (1924)

17. W. R. Ham, J. Chem. Phys., 1, 476 (1932)

18. Metal Hydrides Inc. Progress Reports - NEPA Nos. 836, 855, 891, 969, $1005,1031,1060,1085,1123,1221$ (1948) Confidential

19. O. W. Richardson, J. Nicol, and T. Parnell, Phill. Mag. (6), 8, 1 (1904)

20. D. W. Rudd, D. W. Vose, and M. B. Giusto, Final Report, AT(30-1)-2298

21. D. W. Rudd, D. W. Vose and J. B. Vetrano, "The Permeation of Hydrogen Through Hastelloy B, "NAA-SR-4898, Rev. I 